\title{
The biological effects of fermented camel milk fortified with sage (Salvia officinalis L.) and mint (Mentha piperita) leaves powder on alloxan-induced diabetic rats
}

\author{
Magdy Ramadan Shahein \\ Tanta University \\ Abdelmoneim Ahmed Elmeligy \\ Suez Canal University \\ Mahmoud Ibrahim El-Sayed ( $\square$ mahmoud.elsayed@arc.sci.eg ) \\ Agricultural Research Center
}

\section{Research Article}

Keywords: Camel milk, Fermented milk, Anti-diabetic, Sage, Mint, Antioxidants

Posted Date: February 21st, 2022

DOI: https://doi.org/10.21203/rs.3.rs-1362024/v1

License: (c) (i) This work is licensed under a Creative Commons Attribution 4.0 International License.

Read Full License 
3

4 5

\section{The biological effects of fermented camel milk fortified with sage (Salvia officinalis} L.) and mint (Mentha piperita) leaves powder on alloxan-induced diabetic rats Magdy Ramadan Shahein ${ }^{1}$, Abdelmoneim Ahmed Elmeligy ${ }^{2}$, Mahmoud Ibrahim El-Sayed ${ }^{3}$

${ }^{1}$ Department of Food Science and Technology, Faculty of Agriculture, Tanta University. Tanta, Egypt. ${ }^{2}$ Department of Pathology, Faculty of Veterinary Medicine - Suez Canal University, Ismailia, Egypt.

${ }^{3}$ Department of Dairy Technology Research, Food Technology Research Institute, Agricultural Research Center, Giza, Egypt.

\footnotetext{
Food Technology Research Institute, Agricultural Research Center, Giza, Egypt.
}

* Corresponding author: Mahmoud Ibrahim El-Sayed, Department of Dairy Technology Research,

E.mail: Mahmoud.elsayed@arc.sci.eg ; mahmoud_im1981@yahoo.com

8

9

0

1

2

3

24

5

6

7

8

9

0

1

2

3


Abstract

Background: Diabetes mellitus (DM) is a chronic metabolic condition described by persistent hyperglycemia due to low secretion of insulin, insulin resistance, or a combination of both. Many studies suggested the potential anti-diabetic effect of camel milk and the important role of the bioactive components of mint and sage in decreasing the side effects of diabetes disease. This study was designed to assess the anti-diabetic potential of fermented camel milk fortified with sage or mint leaves powder (1 and $1.5 \%$ ) in alloxan-induced diabetic rats.

Methods: Forty-two adult normal male albino rats were taken for the study where one group was kept as the non-diabetic control group (6 rats) while the other 36 rats were made diabetic by alloxan injection $(150 \mathrm{mg} / \mathrm{kg}$ of body weight). Among diabetic rats, a control (+) group (6 rats) was kept and referred to as diabetic control whereas the other 5 groups (7rats each) of diabetic rats were fed on fermented camel milk (FCM) or fermented camel milk fortified with sage or mint leaves powder( 1 and 1.5\%). Results: The oral administration of fermented camel milk fortified with sage or mint leaves powder caused a significant decreased in blood glucose level and lipid profile, and increased in insulin level compared to the control (+) and FCM groups, and the best results were observed with fermented camel milk fortified with $1.5 \%$ sage powder. The results also found that the fermented camel milk fortified with sage or mint leaves powder improved the liver and kidney functions of diabetic rats. Importantly, treatment of diabetic animals fermented camel milk fortified with sage or mint leaves powder resulted in significant amelioration of the histopathological changes of pancreatic, liver, and kidney observed in diabetic animals.

Conclusion: Our study recommends the use of sage and mint leaves powder (at a ratio of $1.5 \%$ ) with

55 fermented camel milk to produce functional food products with anti-diabetic activity.

Keywords: Camel milk, Fermented milk, Anti-diabetic, Sage, Mint, Antioxidants

\section{Background}

60 According to the most recent food and agriculture organization (FAO) statistics, Camels world 61 population is estimated to be around 32.6 million [1]. Camel's milk is a vital part of the staple diet in 62 several parts of the world, especially in the arid and semi-arid zones. Camel's milk is rich in health- 
beneficial substances, such as lactoferrin, lysozyme, lacto-peroxidase, bioactive peptides, mono and polyunsaturated fatty acids, minerals (calcium, magnesium, copper, iron, zinc, phosphorous, potassium and sodium), immunoglobulins and vitamins including, B1, B2 and C [2,3,4,5]. Camel milk has been known as a source for the production of dairy products with excellent therapeutic properties such as fermented milk [6]. Raw and fermented camel milk is found to have many health benefits such as anticancer, antimicrobial, antioxidant, anti-inflammatory, antidiabetic, anti-diarrhea, hypocholesterolemic, angiotensin I-converting enzyme (ACE) inhibitory activities [7, 8, 9, 10].

According to the available data from IDF confirmed that, in 2021, the number of people (20 to 79-year-old) suffering from diabetes was predestined near 537 million [11] . This number is foreseeable to reach 643 million in 2030 and 783 million by 2045. Diabetes mellitus (DM) is a chronic metabolic condition described by persistent hyperglycemia due to being incapable to produce enough insulin, cannot using the produced insulin (insulin resistance), or a combination of both $[12,13]$. Camel milk is a unique source of nutrients and is considered as a super food with high medicinal values [14]. Camel milk has been shown to improve other pathophysiological aspects related to diabetes as a chronic disease such as obesity, insulin resistance, wound healing, and inflammation $[12,15,16]$. Camel milk improves diabetes complications such as wounds, kidney and liver failures and oxidative stress. Also, Camel milk improves diabetes complications such as liver and kidney failures, wounds, and oxidative stress [17]. Fallah et al. [18] found that the raw camel milk caused an increase in insulin secretion, and reduce bout $30-35 \%$ of required insulin in type 1 diabetes patients.

One therapeutic ways suggested to reduce postprandial hyperglycemia is by the inhibition of two key enzymes linked to type II diabetes mellitus, namely $\alpha$-glucosidase and $\alpha$ - amylase, in the digestive organs. Despite its traditional applications in food flavoring, Mentha spp are widely used for treating not only fever and cold but also cardiovascular and gastrointestinal disorders as folk medicines [19]. Rajeshwari et al. [20], reported that the administration of mint leaves powder (5g/day) to type 2 diabetes patients for 60 days reduced the oxidative stress by decreased lipid peroxidation, protein oxidation, increased serum beta carotene, vitamin A, E, and C levels. In addition, improved the activity of some antioxidant enzymes i.e. glutathione-S-transferase (GST), in addition to the content of reduced glutathione (GSH). Also, Chandirasegaran et al. [21] detected a significant decrease in blood glucose and creatinine levels as well as an increase in insulin levels of diabetic rats after being treated with mint (300 mg/kg B.W) for 45 days. These findings cleared that mint possesses antidiabetic activity against streptozotocin-induced diabetic rats. 
Sage is well reputed to cure diabetes or restrain its complications [22]. Khashan and AlKhefajim [23] found that the treatment of alloxan-induced diabetic rats with aqueous and ethanol extracts of Salvia officinalis leaves at a concentration (100 mg/kg B.W) for 14 days decreased the levels of blood glucose, triglycerides, and total cholesterol. The suggested mechanisms for anti-diabetic actions of salvia species extracts are the increase of insulin sensitivity, activation of pancreatic b-cells, and peripheral use of glucose, inactivation of insulinase enzyme, glycogenolysis reduction, decreases the absorption of glucose from the intestine, and increase the synthesis of glucose in the liver [24]. The present study aimed to evaluate the effects of camel milk fortified with sage and mint leave powder on the biochemical markers and histopathological of the alloxan-induced diabetic rats.

103

104

\section{Material and Methods}

\section{Materials}

106 Camel milk (total solids $11.84 \%$, protein $3.22 \%$, fat $3.43 \%$, pH 6.60, and acidity $0.175 \%$ ) was obtained from a private farm in El-Arish, North Sinai Governorate, Egypt. Commercially- vailable lyophilized culture (Yo-fast 88, contains Streptococcus thermophillus and Lactobacillus delbrueckii ssp. bulgaricus) was purchased from Chr. Hansen Laboratories, Hoersholm, Denmark. Mint (Mentha piperita) and Sage (Salvia officinalis) leaves were obtained from El-Arish local market, North Sinai Governorate, Egypt. Alloxan monohydrate, analytical reagent grade purchased from Sigma Chemical Co. (Sigma-Aldrich Company Ltd., UK). 1, 1-diphenyl-2-picryl-hydrazyl (DPPH) was purchased from Sigma-Aldrich

(Munich, Germany). Potassium ferricyanide, Ferric chloride and gallic acid were purchased from Loba Chemie, Mumbai, India.

\section{Methods}




\section{Antioxidant activity of sage and mint extracts}

\section{Determination of total phenolic contents of sage and mint extracts}

TP contents of sage and mint extracts were determined according to the method of Abirami et al. [26]. Folin-Ciocalteu's reagent $(1.5 \mathrm{~mL}$, diluted 10 times $)$ and $\mathrm{Na} 2 \mathrm{CO} 3(1.2 \mathrm{~mL}, 7.5 \% \mathrm{w} / \mathrm{v})$ were added to sage and mint extracts extract $(300 \mu 1)$. Mixtures were shaken and kept at room temperature for 30 min (in dark) before measuring absorbance at $765 \mathrm{~nm}$ using a spectrophotometer (Pg T80+, England), tests were carried out in triplicate. Total phenol content (TPC) was expressed as Gallic acid equivalent (mg GAE/g plant material or extract).

\section{Determination of total flavonoids (TF)}

The TF content of sage and mint extracts were determined based on the method of Barros et al. [27]. Half milliliter of sage and mint extracts was mixed with distilled water $(2 \mathrm{ml})$ followed by addition of $\mathrm{NaNO}_{2}(150 \mu \mathrm{L}, 5 \%)$ solution. After $6 \mathrm{~min}, 150 \mu \mathrm{L}$ of $\mathrm{AlCl}_{3}(10 \% \mathrm{w} / \mathrm{v})$ was added and allowed to stand for another $6 \mathrm{~min}$ before $2 \mathrm{ml}$ of $\mathrm{NaOH}(4 \% \mathrm{w} / \mathrm{v})$ was added. The last mixture was brought to $5 \mathrm{~mL}$ with distilled water, and then allowed to stand for $15 \mathrm{~min}$ at room temperature. The absorbance was measured at $510 \mathrm{~nm}$ using a spectrophotometer (Pg T80+, England). A calibration curve of Rutin was prepared and TF content was determined.

\section{DPPH scavenging activity \%}

Scavenging activity of 1,1-diphenyl-2-picrylhydrazyl (DPPH) radical was determined according to the method of Lim and Quah [28]. Two milliliters of $0.15 \mathrm{mM} \mathrm{DPPH}$ was added to $1 \mathrm{ml}$ of extracts in different dilutions. A control was prepared by adding $2 \mathrm{ml}$ of DPPH to $1 \mathrm{ml}$ of methanol. The contents of the tubes were mixed and allowed to stand for $30 \mathrm{~min}$, and absorbance was measured at $517 \mathrm{~nm}$ using a spectrophotometer (Pg T80+, England). Triplicate tubes were prepared for each extract. The results were expressed as \% radical scavenging activity.

$$
\text { Radical scavenging activity } \%=\frac{(\text { A control }- \text { A sample })}{\text { Acontrol }} \times 100
$$

$\mathrm{IC}_{50}$ which denotes the amount $(\mathrm{mg})$ of the plant powder in $1 \mathrm{ml}$ solution required to reduce initial concentration of DPPH radicals by $50 \%$ was also calculated. Ascorbic acid was used as a standard.

\section{Ferric reducing antioxidant power (FRAP)}


154 The FRAP was determined according to the method of Oyaizu [29]. One milliliter of sage and mint 155 extracts in different dilutions was added to $2.5 \mathrm{ml}$ phosphate buffer $(\mathrm{pH} 6.6,0.1 \mathrm{M})$ and $2.5 \mathrm{ml}$ 156 potassium ferricyanide $(1 \% \mathrm{w} / \mathrm{v})$. Then the mixture was incubated in a water bath at $50^{\circ} \mathrm{C} / 20 \mathrm{~min}$, 157 followed by cooling to room temperature and adding $2.5 \mathrm{~mL}$ of trichloroacetic acid $(10 \% \mathrm{w} / \mathrm{v})$. The 158 contents of the tubes were centrifuged at $10,000 \times \mathrm{g}$ for $10 \mathrm{~min}$ at $4^{\circ} \mathrm{C}$. Two and half milliliters of 159 supernatant was removed from each tube, and then mixed with of distilled water $(2.5 \mathrm{~mL})$ and ferric 160 chloride solution $(0.5 \mathrm{~mL}, 0.1 \% \mathrm{w} / \mathrm{v})$. The mixtures were allowed to stand for $30 \mathrm{~min}$ in dark at room 161 temperature. The absorbance measurements were taken at $700 \mathrm{~nm}$ using a spectrophotometer (Pg T80+, 162 England). Triplicate tubes were prepared for each extract. The FRAP values, expressed in mg GAE/g, 163 were derived from a standard curve.

\section{Physicochemical analysis of camel milk}

166 Total solids (\%), protein (\%) and fat (\%) of camel milk were determined using the AOAC procedures 167 [30]. The $\mathrm{pH}$ of camel milk was measured using a digital pH meter (Martini, Italy). Titratable acidity 168 (lactic acid \%) of raw camel milks was evaluated by titration with $\mathrm{NaOH}(0.1 \mathrm{~N})$ in the presence of phenolphthalein as an indicator. All analyses were performed in triplicate.

\section{Preparation of fermented camel milk's (FCMs)}

172 Camel milk was divided into five portions. The first portion served as a control (FCM). Four portions of 173 camel milk were supplemented with sage and mint leave powder at levels of 1 and 1.5\% (FCMS1(1\% sage), FCMS2 (1.5\% sage), FCMM1 (1\% mint), and FCMM2 (1.5\% mint)). Fermented milk was prepared according to Tamime and Robinson [31]. Camel's milk was heated at $72{ }^{\circ} \mathrm{C} / 15 \mathrm{sec}$, cooled to $40^{\circ} \mathrm{C}$, and then inoculated with $0.3 \%$ yoghurt starter culture. Camel milk was incubated at $42 \pm 1{ }^{\circ} \mathrm{C}$ until the $\mathrm{pH}$ value was decreased to approximately 4.6. The resultant fermented camel milk of all treatments was kept in a refrigerator $\left(4 \pm 1^{\circ} \mathrm{C}\right)$ until use.

\section{The induction of experimental diabetes:}

182 Alloxan was dissolved in saline solution (0.9\% sodium chloride, $\mathrm{pH} 7)$. Diabetes was induces in normal 183 healthy male albino rats by received intra-peritoneal injection dose of alloxan $150 \mathrm{mg} / \mathrm{kg}$ body weight, according to the method described by Desai and Bhide [32]. After three days of the injection with 
alloxan, fasting blood samples were obtained to estimate fasting serum glucose higher than $200 \mathrm{mg} / \mathrm{dL}$ rats which were considered diabetes by The National Diabetes Data Group [33].

\section{Experimental design}

The experimental protocol was approved by Research Ehtical Committee (REC), The Institutional Animal Care and Use Committee (ICUC), Tanta University, Egypt, (Approval number: IACUC-SCI-

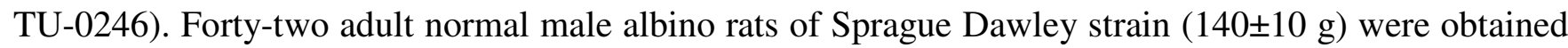
from Vaccine and Immunity Organization, Ministry of Health, Helwan, Egypt. Animals were housed 6 per cage and fed on basal diet prepared base on American Institute of Nutrition [34] and consisting of $12 \%$ casein, $10 \%$ sugars, $10 \%$ sun flower oil, $1 \%$ vitamin mixtures, $4 \%$ mineral mixtures, $4 \%$ fiber, $58.50 \%$ starch, $0.3 \%$ DL-methionin and $0.2 \%$, choline chloride, and given free access to fresh water ad libitum. Rats were acclimated for 2 weeks at $25 \pm 1{ }^{\circ} \mathrm{C}$ with a 12-h dark and light cycle [35]. The experimental period was 8 weeks after stabilization of diabetes for 1 week and the animals were divided into 7 major groups (6 rats per group) as follows:

Group 1: healthy rats (negative control); Group 2: positive diabetes control (positive control);

Group 3: Diabetic rats received fermented camel milk without additives (FCM); Group 4: Diabetic rats received fermented camel milk supplemented with $1.0 \%$ (W/V) leaves powder sage (FCMS1);

Group 5: Diabetic rats received fermented camel milk supplemented with $1.5 \%(\mathrm{~W} / \mathrm{V})$ leaves powder sage (FCMS2); Group 6: Diabetic rats received fermented camel milk supplemented with $1.0 \%$ (W/V) mint leaves powder (FCMM1); Group 7: Diabetic rats received fermented camel milk supplemented with $1.5 \%(\mathrm{~W} / \mathrm{V})$ mint leaves powder (FCMM2).

Fermented camel milks were given orally by gavages daily for eight weeks. The oral dose of fermented camel milk was $85 \mathrm{ml} / \mathrm{kg} \mathrm{B.W} /$ day, based on the study of Althnaian et al. [36]. At the end of the experimental period, rats were fasted for $12 \mathrm{~h}$, anesthetized with ether, and killed. Fasting blood samples were collected in heparinized tubes from the killed animals, and then centrifuged at 7,200 $\times$ gat $4{ }^{\circ} \mathrm{C}$ for 20 min (Sigma centrifuge 113, VWR International) to obtained plasma. The obtained plasma was stored at $-80^{\circ} \mathrm{C}$ until used for analyses [37].

\section{Blood biochemical and enzymes activities}

Stored plasma samples were analyzed for plasma glucose concentration according to the method of Trinder [38], National Diabetes Data Group [39]. Urea was determined according to the method of 
216 Chaney and Marbach [40], Searcy et al. [41], Tabacco et al. [42]. Creatinine was determined according 217 to the method of Bartels and Böhmer [43], Fabiny and Ertingshausen [44]. Triglycerides was determined 218 according to the method of Bucolo and David [45], Fossati and Prencipe [46]. Cholesterol was 219 determined according to the method of Meiattini et al. [47]. High-density lipoprotein (HDL) cholesterol 220 was determined according to the method of Grove [48], Burstein et al. [49]. Low-density lipoprotein 221 (LDL) was determined by the calculation (cholesterol-(TG/5+HDL). Very low-density lipoprotein 222 (VLDL) was calculated by dividing the values of TG by factor of 5. The activities of plasma aspartate 223 transaminase (AST) and alanine transaminase (ALT) were assayed by the method of Reitman and 224 Frankel [50]. Alkaline phosphatase (AlP) activity was determined in plasma according to the method of 225 Belfield and Goldberg [51]. Commercial kitts of the previous assays were obtained from Biosystems 226 S.A. (Spain) (for Glucose, Cholesterol, HDL, TG, Urea, Creatinine); QUIMICA CLINICA APLICADA 227 S.A (Spain) (for AST, ALT); Biodiagnostic (ARE) (for ALP).

Determination of blood insulin level

Insulin levels were estimated according to Abraham et al. [52] and Wilson and Miles [53] by using ELISA kit by Linco Research Inc. USA.

\section{Histopathological investigation:}

Small specimens of the organs (liver, kidney and spleen) were taken from each experimental group. Fixed in neutral buffered formalin, dehydrated in ascending concentration of ethanol (70, 80 and 90\%), cleared in xylene and embedded in paraffin. Histopathology examinations were described according to Bancroft et al. [54].

\section{Statistical analysis:}

The data were analyzed using a completely randomized factorial design when a significant main effect was detected; the means were separated with the Student-Newman-Keuls Test. Differences between treatments of $(\mathrm{P} \leq 0.05)$ were considered significant using Cost at Program. Biological results were 


\section{Antioxidant activity of saga and mint leaves powder}

Many studies noted that the components with combined antioxidant potential anti-diabetic and antiglycation properties such as Mentha arvensis extracts are effectively used to treat diabetes mellitus [55].

Data in Table (1) showed the antioxidant activity of mint and sage extracts. The results found that sage extract was higher in total phenolic contentment (7.35 mg GAE/g) than mint extract (7.35 $\mathrm{mg} \mathrm{GAE} / \mathrm{g})$, while, the mint extract was the highest in total flavonoids $(184 \mu \mathrm{g} / \mathrm{ml})$. Moreover, the higher DPPH scavenging activity (\%) was found with sage extract, while, the higher FRAP value was observed with mint extract.

\section{Effect of fermented camel milk on alloxan-induced diabetic rats}

\section{Serum glucose and Insulin determination}

The anti-diabetic properties of camel milk are very complex involving many cellular and molecular mechanisms and aspects of metabolism and transport of glucose as well as the synthesis and secretion of insulin $[56,57]$.

Data presented in Figure (5) showed the effect of fermented camel milk fortified with sage and mint leaves powders by ratio 1 and $1.5 \%$ on plasma glucose and insulin levels of diabetic rats. Results indicated that higher plasma glucose level $(253 \mathrm{mg} / \mathrm{dl})$ was observed with the positive control group. On the other hand, the oral intake of fermented camel milk with or without fortification by sage and mint leaves powders significantly $(\mathrm{P}<0.05)$ decreased the plasma glucose level in diabetic rats, while the normal rats was not affected. The oral intake of fermented camel milk fortified with saga and mint powder (FCMM1 ,FCMM2, FCMS1 and FCMS2) caused a significantly decreased in plasma glucose 
276 level compared with the group of fermented camel milk (FCM), and the higher decreased was found 277 with FCMM2 and FCMS2 groups (186.3 and $175.2 \mathrm{mg} / \mathrm{dl}$, respectively). The induction with alloxane 278 caused a significant $(\mathrm{P}<0.05)$ decreased in the insulin level in rats plasma (Figure 1). The higher 279 significant $(\mathrm{P}<0.05)$ decreased was observed with positive control group $(8.2 \mu \mathrm{U} / \mathrm{ml})$, while the oral 280 intake of fermented camel milk with or without sage and mint powder significantly $(\mathrm{P}<0.05)$ increase 281 the insulin level in the blood again. The results showed that the higher insulin levels were observed with 282 negative control group $(35.9 \mu \mathrm{U} / \mathrm{ml})$ followed by the animal groups intake fermented camel milk 283 fortified with 1 and $1.5 \%$ sage powder (29.11 and $30.2 \mu \mathrm{U} / \mathrm{ml}$, respectively), while, no significant 284 (P>0.05) differences were found between FCM, FCMM1 and FCMM2 groups (27.3, 27.4 and 28.6 $285 \mu \mathrm{U} / \mathrm{ml}$, respectively).

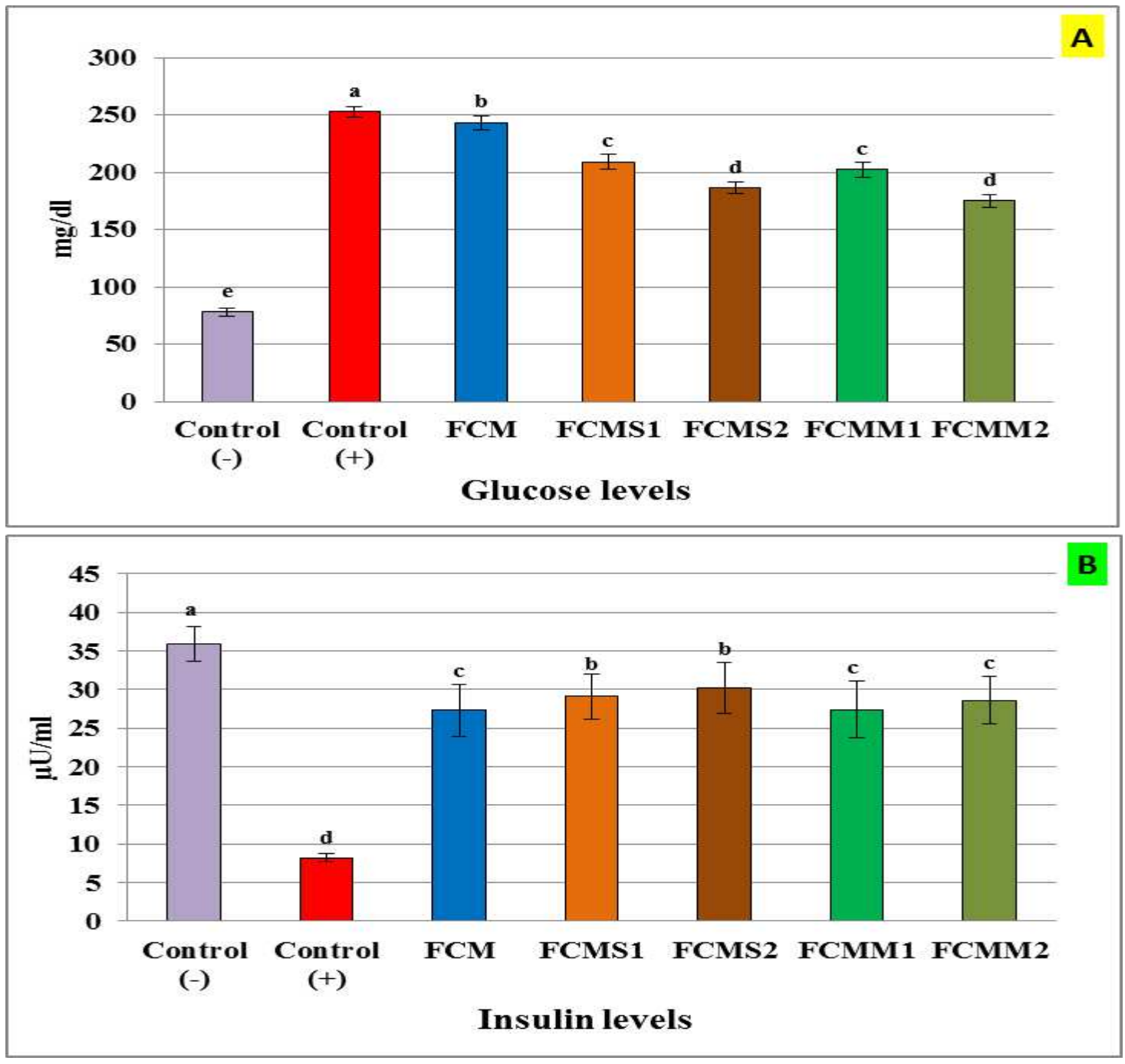


308 Figure (1): Effect of fermented camel milk fortified with sage and mint leave powders on glucose and insulin levels of normal and diabetic rats. Control (-): normal healthy rats; Control (+): control diabetic rats; FCM: fermented camel milk, FCMS1: fermented camel milk with $1.0 \%$ sage leave powder, FCMS2: fermented camel milk with 1.5\% sage leave powder, RCMM1: fermented camel milk with 1.0\% mint leave powder, FCMM2: fermented camel milk with 1.5\% mint leave powder. Values are expressed as mean $\pm S D, n=6$, Mean values in each column having different superscript $a, b, c$, $d$ are significant at $314(p<0.05)$ by different and vice versa.

\section{Lipid profile}

Data in Figure (2) showed that after eight weeks of animals induction using alloxan, the animal untreated with fermented camel milk $($ control +) displayed an increase in plasma total triglyceride (TG) and total cholesterol (TC) compared with control (-) and animal groups treated with fermented camel milk (FCM with or without mint and sage powders (FCMS and FCMM). The results showed that the oral administration of FCM or FCMS and FCMM significantly decreased TG and TC in diabetic rats groups. A higher decrease in TG and TC levels was found with FCMS2 and FCMM2 groups compared to FCMS1, FCMM1, and FCM groups.

The results cleared that the oral administration of fermented camel milk (FCM) or fermented camel milk fortified with 1 and $1.5 \%$ of sage or mint powder (FCMS and FCMM) caused a significant decrease in low-density lipoprotein cholesterol (LDL-c) and very-low-density lipoprotein cholesterol (VLDL-c) levels compared with control(+) group, while the high-density lipoprotein cholesterol (HDLc) was significantly increased. The higher decrease in LDL values was found with FCMS2 and FCMM2 groups and there were no significant differences between the two groups, while, the lowest value of VLDL was observed with FCMM2. Also, higher values of HDL were found with FCMM2 and FCMS2 groups compared with all other groups. From these results, it could be concluded that the oral administration of fermented camel milk fortified with sage and mint powder by a ratio of 1 and $1.5 \%$ improved the lipid profile of diabetic rats, and the best results were found with an addition ratio of $1.5 \%$ of each herpes powder. 
Figure (2): Effect of fermented camel milk fortified with sage and mint leave powders on lipid profile in plasma of normal and diabetic rats. Control (-): normal healthy rats; Control (+): control diabetic rats; FCM: fermented camel milk, FCMS1: fermented camel milk with 1.0\% sage leave powder, FCMS2: fermented camel milk with 1.5\% sage leave powder, RCMM1: fermented camel milk with 1.0\% mint leave powder, FCMM2: fermented camel milk with 1.5\% mint leave powder. Values are expressed as mean $\pm S D, n=6$, Mean values in each column having different superscript $a, b, c$, $d$ are significant at 


\section{Liver functions}

369 In the current study, 8 weeks of treatment of diabetic rats with fermented camel milk's significantly improved liver functions as evidenced by the following observations. Induction of rats with alloxan 371 alone (control $(+)$ group) caused a significant $(\mathrm{P}<0.05)$ increase in ALP, AST, and ALT compared with the healthy control group (Figure 3). These increases in ALP and AST were significantly $(\mathrm{P}<0.05)$ decreased after being treated with FCM (FCM group) and FCM fortified with 1 or $1.5 \%$ of sage and mint powder. Meanwhile, the values of ALT were significantly $(\mathrm{P}<0.05)$ decreased in FCMS1, FCMS2, and FCMM2 groups, while, FCM and FCMM1 were not affected, compared with the control (+) group. The treatment with fermented camel fortified with $2 \%$ sage powder (FCMS2 group) reduced the increase in liver functions to be close to the normal range. No significant $(\mathrm{P}>0.05)$ differences were observed between FCMS1 and FCMM2.

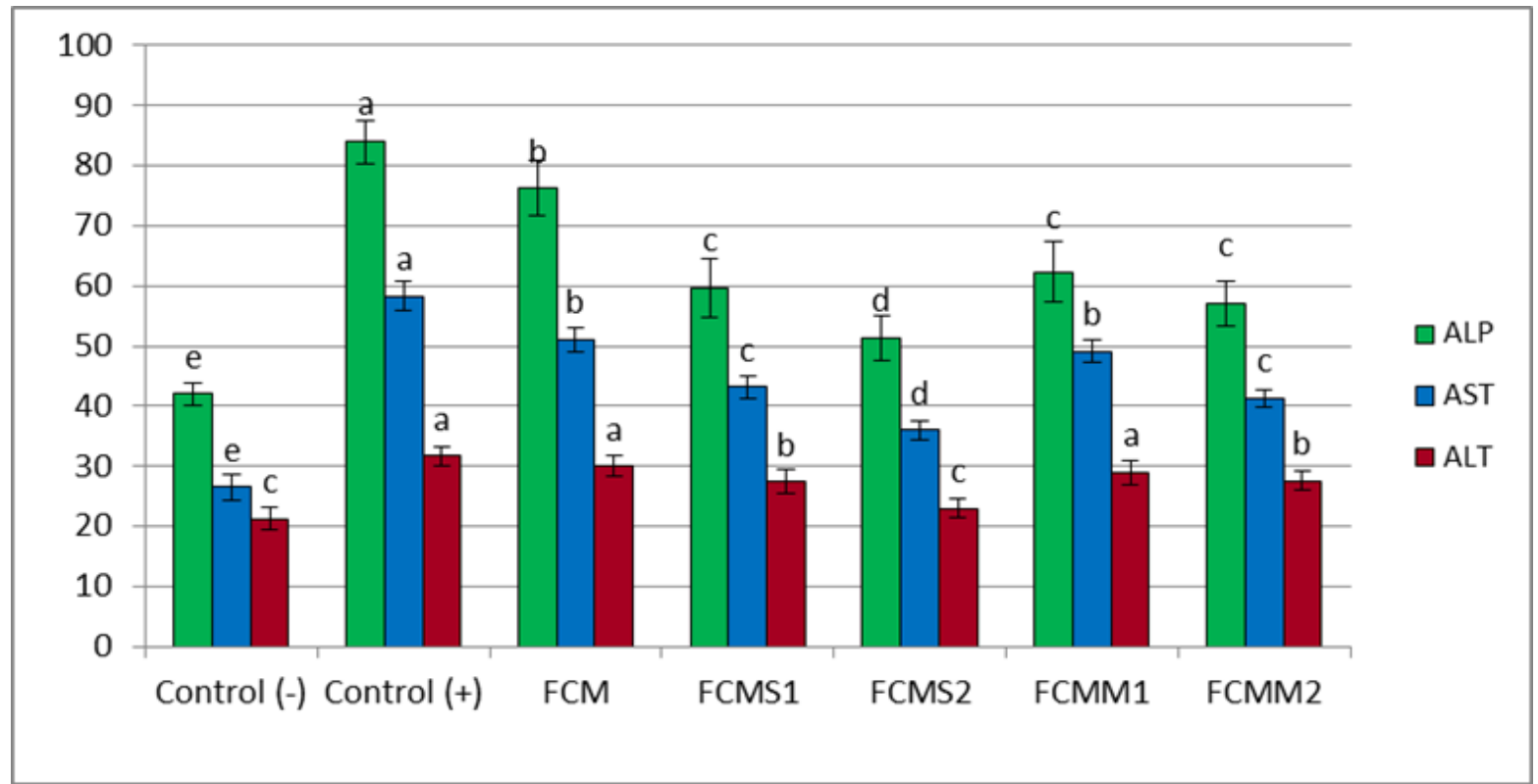

Figure (3): Effect of fermented camel milk fortified with sage and mint leave powders on liver enzymes in plasma of normal and diabetic rats. Control (-): normal healthy rats; Control (+): control diabetic rats; FCM: fermented camel milk, FCMS1: fermented camel milk with $1.0 \%$ sage leave powder, FCMS2: fermented camel milk with 1.5\% sage leave powder, RCMM1: fermented camel milk with 1.0\% mint leave powder, FCMM2: fermented camel milk with 1.5\% mint leave powder. Values are expressed 
401

$402 \quad$ Kidney functions

403 A serious complication of diabetes disease is diabetic nephropathy (DN), which is the most popular 404 cause of chronic kidney disease, especially in western countries, affecting 30-40\% of patients with type 4051 and type 2 diabetes [58]. The induction of rats with alloxan significantly $(\mathrm{p}<0.05)$ increased serum 406 urea and creatinine levels and the high values was found with positive control group as compared to 407 negative control group. Treatment with FCM or FCM fortified with sage and mint powder significantly 408 decreased of serum urea and creatinine levels. The higher decease in urea level was observed with 409 fermented camel milk samples containing of $1.5 \%$ of sage or mint powder (FCS2 and FCMM2) 410 followed by the samples containing $1 \%$ of sage and mint powder (FCS1 and FCMM1), then sample of 411 FCM alone. Concerning of creatinine level in diabetic rats groups, the results showed that the creatinine 412 levels was significantly decreased administration of FCM, FCMS and FCMM, and the higher decreased 413 was found with FCMS1, FCMS2 and FCMM2, followed by FCMM1 and FCM groups. 

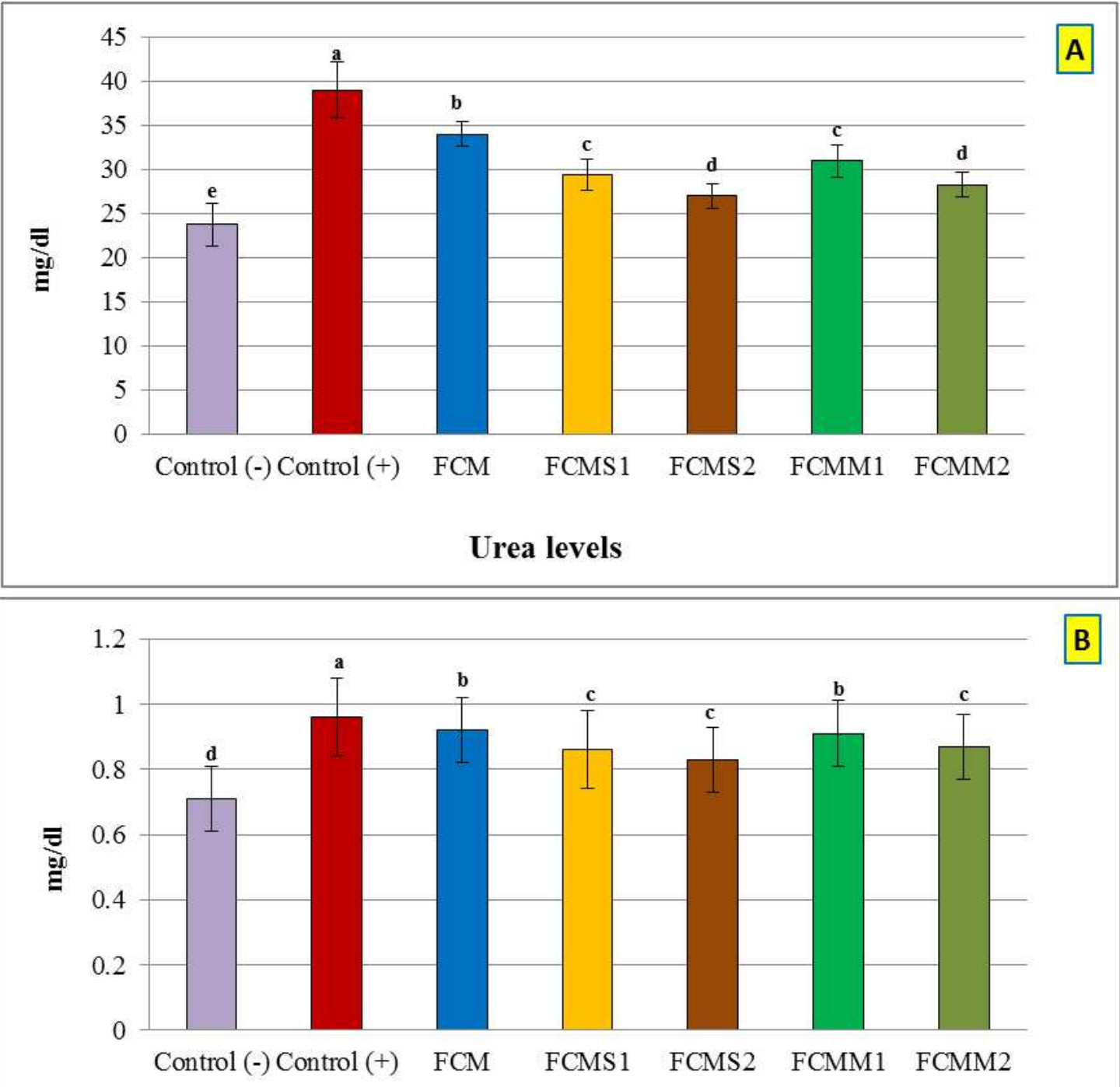

\section{Creatinine levels}

Figure (4): Effect of fermented camel milk fortified with sage and mint leave powders on urea and 437 creatinone levels of normal and diabetic rats. Control (-): normal healthy rats; Control (+): control diabetic rats; FCM: fermented camel milk, FCMS1: fermented camel milk with 1.0\% sage leave powder, FCMS2: fermented camel milk with 1.5\% sage leave powder, RCMM1: fermented camel milk with 1.0\% mint leave powder, FCMM2: fermented camel milk with 1.5\% mint leave powder. Values are expressed 441 as mean $\pm S D, n=6$, Mean values in each column having different superscript $a, b, c$, $d$ are significant at 442 $(p<0.05)$ by different and vice versa. 


\section{Histopathological examination}

446

447

448

449

450

451

452

453

454

455

456

457

458

459

460

461

462

463

464

465

466

467

468

469

470

471

472

473

474

475

\section{Histopathological of pancreatic tissues}

Microscopic examination of pancreatic tissue of the normal control (-) group showed normal pancreatic parenchyma with alveolar shaped and closely packed acini, normal pancreatic ducts and ductules, and normal pancreatic islets (Fig. 5A). While pancreatic tissue of the control positive group revealed necrotic pancreatitis with hyperplasia in pancreatic islets and vasculitis with thick muscle walled blood vessel and leucocytic cells infiltration (Fig. 5B). Moreover, the pancreatic tissue of FCM group showed slight hyperplasia in the pancreatic islets $\left(^{*}\right)$ and slightly improved pancreatic parenchyma (Fig. 5C). The pancreatic tissue of FCMS1showing hyperplasia in the pancreatic duct (arrow) with slightly improved pancreatic parenchyma (Fig. 5D). While the pancreatic tissue of the FCMS2 group showed markedly improved pancreatic parenchyma which appeared healthy with normal pancreatic acini (Fig. 5E). Moreover, the pancreatic tissue of the group treated with fermented camel milk fortified with $1.0 \%$ mint (FCMM1) showed congested blood vessels with vasculitis (arrows), the pancreatic parenchyma showed slight improvement (Fig. 5F). While the pancreatic tissue of FCMM2 showed markedly improved pancreatic parenchyma which appeared healthy with normal pancreatic acini (Fig. 5G).

\section{Histopathological of liver tissues}

Liver of normal control (healthy) rats group revealed the normal histological structure of hepatic lobule (Fig. 6 a). Some liver sections of untreated diabetic rat group (positive control) showed vacuolar degeneration of hepatocytes, congestion of hepatic sinusoids and hepatic necrosis with inflammatory cell infiltration (Fig. 6 B). Meanwhile, another liver section of FCM treated group showed cytoplasmic vacuolization of hepatocytes and presence of few leucocytes in the hepatic sinusoids (Fig. 6 C). The liver sections from FCMS1group showed congestion of hepatic sinusoids with mononuclear cells infiltration (Fig. 6 D). Also, the examined liver sections of FCMS2 group showed no histopathological changes (Fig. 6 E). Whereas, the examined liver sections of FCMM1group showed slight hydropic degeneration of hepatocytes and hypergranular cytoplasm (Fig. 6 F). However, the examined liver sections of FCMM2 group showed slight hydropic degeneration of hepatocytes and hypergranular cytoplasm (Fig. 6G). 
478 Microscopically, kidney of normal control rat group revealed normal histological structure of renal 479 parenchyma (Fig.7A). Some examined kidney sections of positive control rat group revealed 480 hypertrophy of glomerular tuft and thickening of parietal layer of Bowman's capsule (Fig. 7B). 481 Moreover, the kidney sections of the FCM group showed revealed cystic dilatation of renal tubules with 482 cellular cast in their lumen (Fig. 7C). Meanwhile, the kidney sections of FCMS1 treated group showing 483 no histopathological changes (Fig. 7D). The examined kidney sections of the FCMS2 group showed 484 cystic dilatation of renal tubules (Fig. 7E). The examined kidney sections of the treated FCMM1 group 485 showed peritubular leucocytic cells infiltration (Fig. 7F). However, the examined kidney sections of the 486 treated rats of FCMM2 group revealed no histopathological changes (Fig. 7G). 


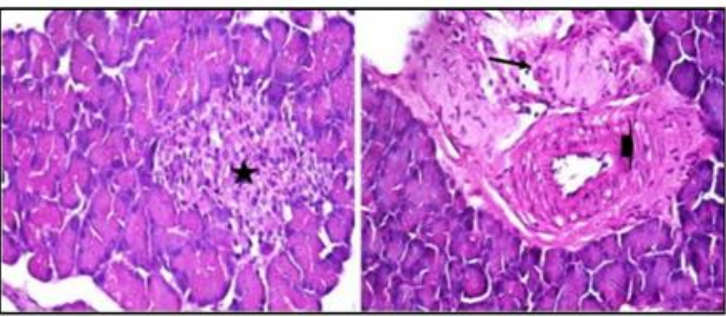

A

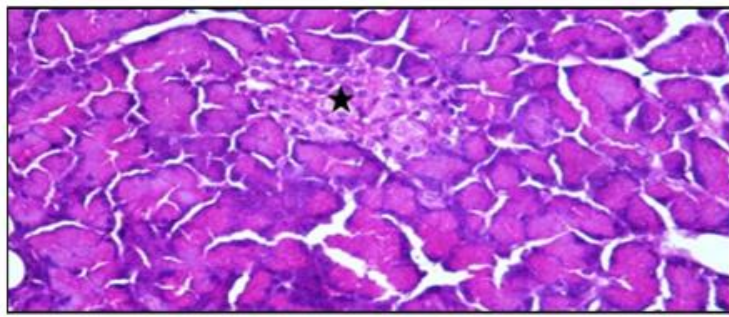

c

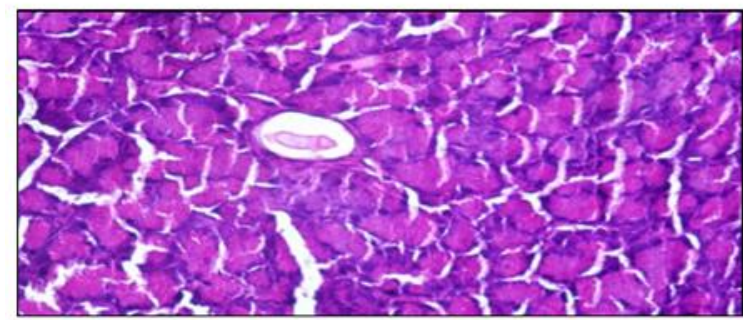

E

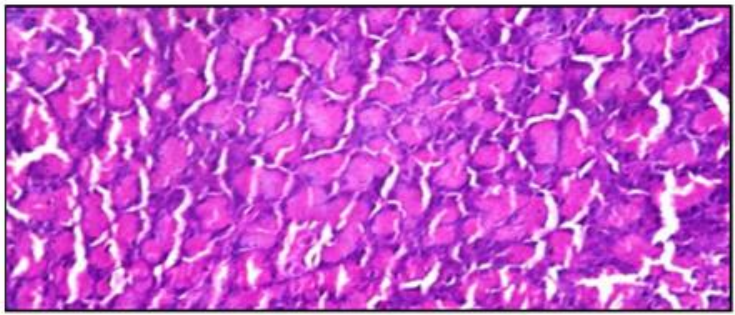

G
B

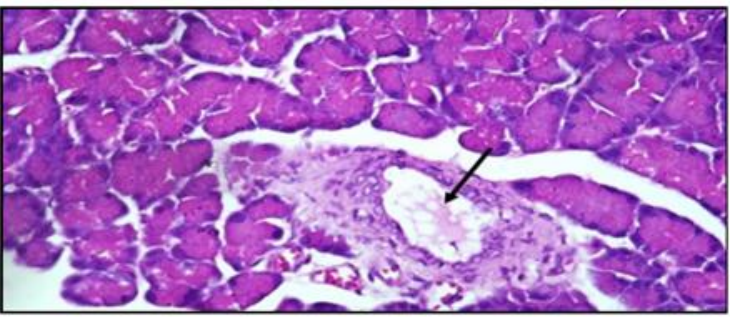

D

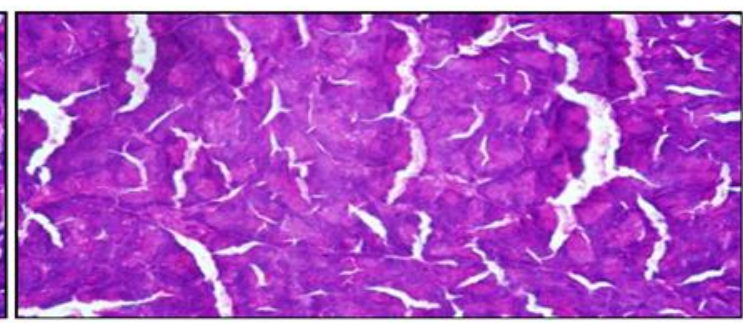

$\mathbf{F}$

Figure (5) Effect of fermented camel milk fortified with sage and mint leaves powder treatment on pancreatic histopathology of the control and diabetic rats. A) normal healthy rats (Control-); B) control diabetic rats (Control +) ; C) fermented camel milk (FCM group);

D) fermented camel milk with 1.0\% sage leave powder (FCMS1 grouop), E) fermented camel milk with 1.5\% sage leave powder (FCMS2 group), F) fermented camel milk with $1.0 \%$ mint leave powder(RCMM1 group ), G) fermented camel milk with 1.5\% mint leave powder (FCMM2 group). 


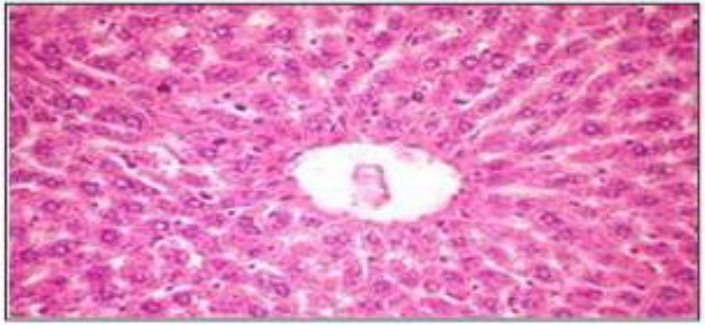

A

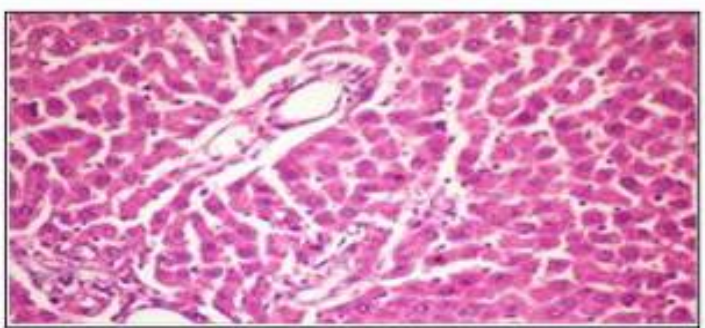

C

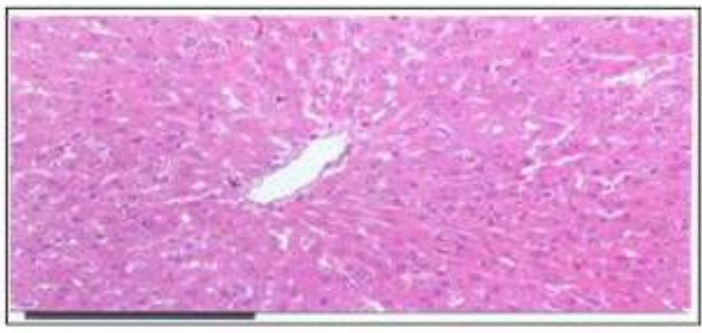

E

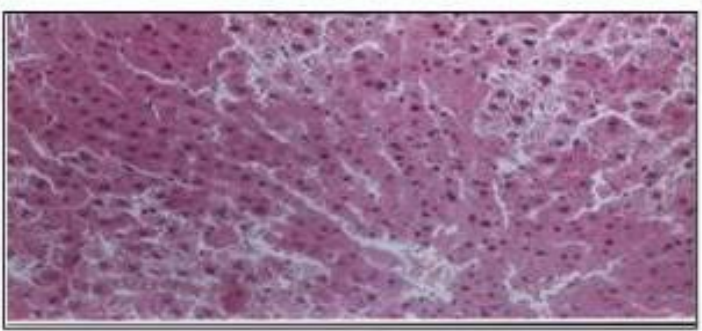

G

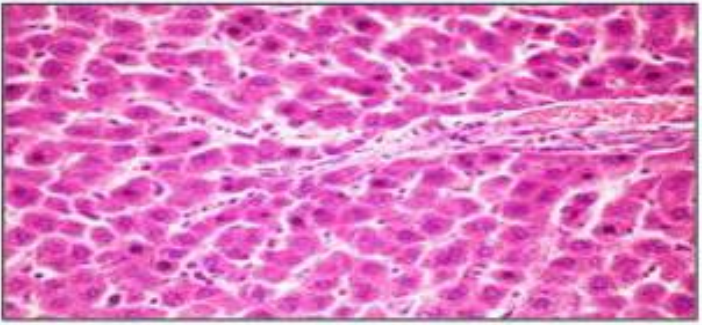

B

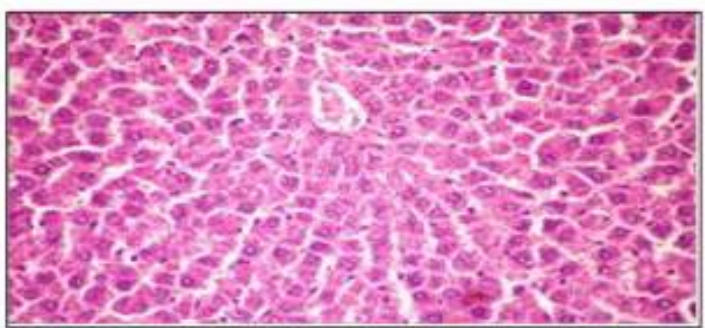

D

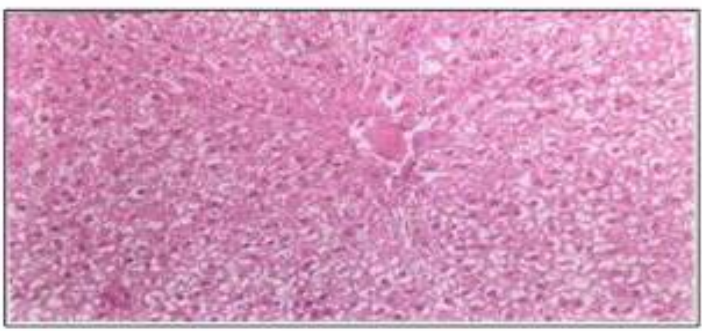

$\mathbf{F}$

Figure (6) Effect of fermented camel milk fortified with sage and mint leaves powder treatment on liver histopathology of the control and diabetic rats. A) normal healthy rats (Control-); B) control diabetic rats (Control +) ; C) fermented camel milk (FCM group); D) fermented camel milk with 1.0\% sage leave powder (FCMS1 grouop), E) fermented camel milk with 1.5\% sage leave powder (FCMS2 group), F) fermented camel milk with 1.0\% mint leave powder(RCMM1 group ), $\boldsymbol{G})$ fermented camel milk with $1.5 \%$ mint leave powder (FCMM2 group). 
572

573

574

575

576

577

578

579

580

581

582

583

584

585

586

587

588

589

590

591

592

593

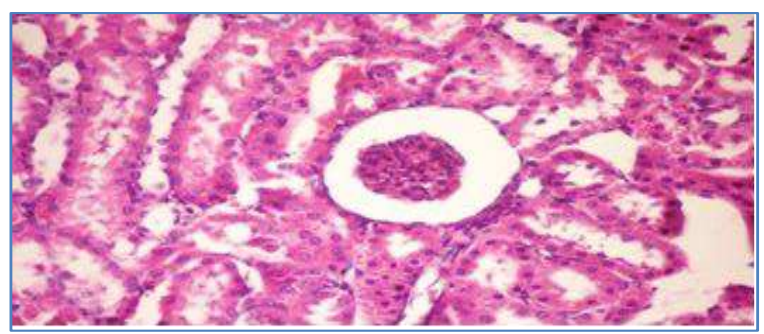

G

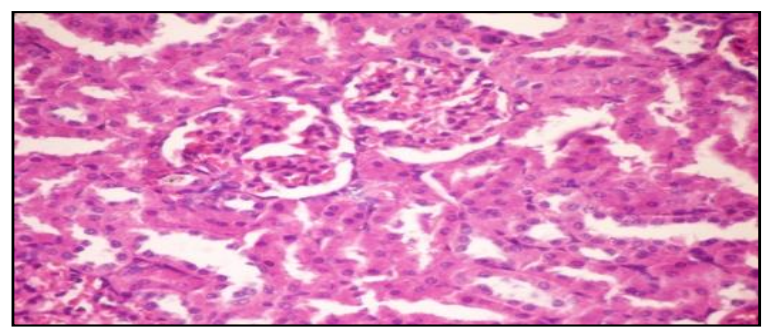

A

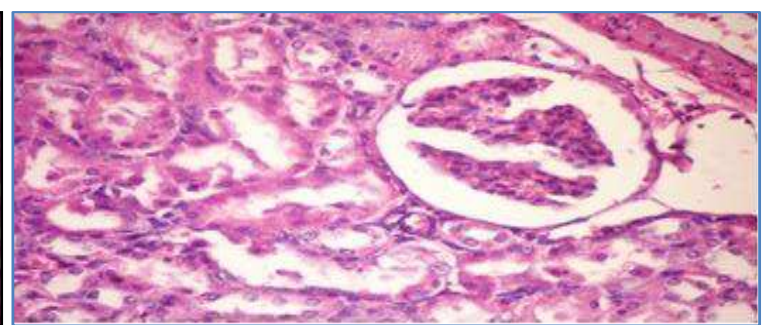

B

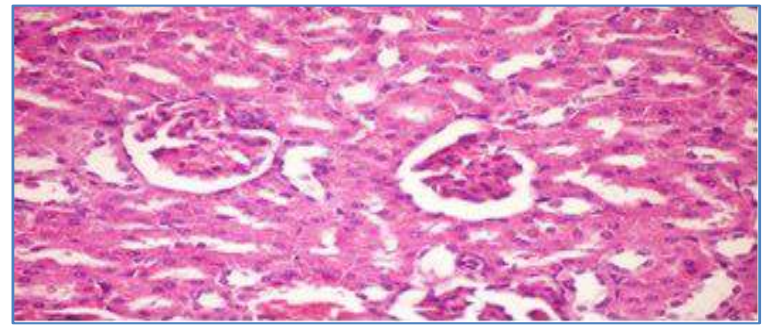

C

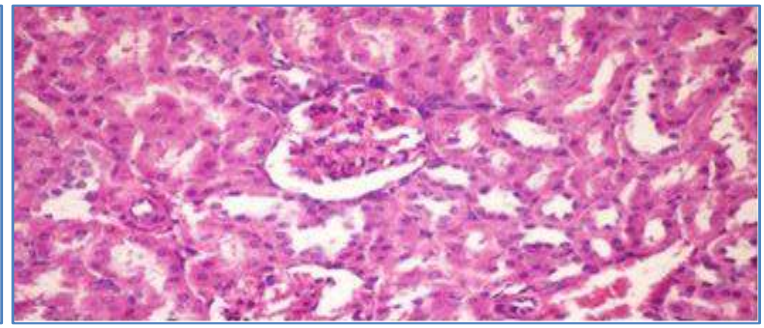

D

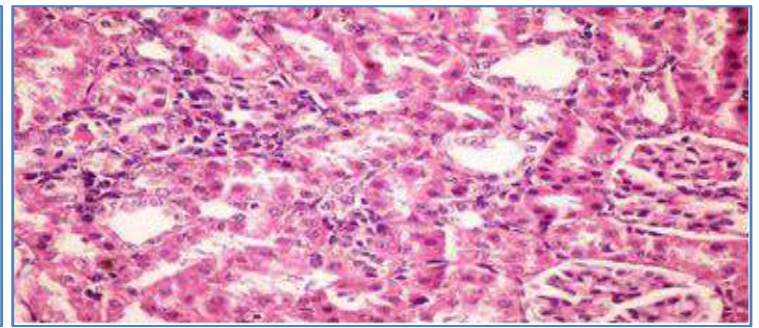

$\mathbf{F}$

Figure (7) Effect of fermented camel milk fortified with sage and mint leaves powder treatment on kidney histopathology of the control and diabetic rats. A) normal healthy rats (Control-); B) control diabetic rats (Control +) ; C) fermented camel milk (FCM group); D) fermented camel milk with $1.0 \%$ sage leave powder (FCMS1 grouop), $\boldsymbol{E}$ ) fermented camel milk with $1.5 \%$ sage leave powder (FCMS2 group), F) fermented camel milk with 1.0\% mint leave powder(RCMM1 group ), $\boldsymbol{G}$ ) fermented camel milk with 1.5\% mint leave powder (FCMM2 group). 


\section{Discussion}

595 In the present study, we confirmed that the supplementation of fermented camel milk with sage and mint 596 powder increased its antidiabetic effects on alloxan-induced diabetic rats. Whereas, the oral 597 administration of fermented camel milk fortified with sage and mint powder caused a significant 598 decrease in blood glucose level and lipid profile and increased in insulin level compared to the control 599 (+) and FCM groups. Many studies reported the relationship between the antioxidant components in 600 medicinal herbs such as sage and mint and potential anti-diabetic properties. Menthol and other volatile 601 602 compounds in the leaves of M. piperita may be responsible for antioxidant and antioxidant activities [59]. Also, mint (M. piperita) leaf extract possesses high amount of phenolic content, flavonoids content,

603 604 605 606 607 608 609 610 611 and flavonols. Rosmarinic acid, caffeic acid and its derivatives, and chlorogenic are the main phenolic compounds of the genus Mentha as well as present of some salvianolic acids [19, 60]. In vitro assays have shown free radical (hydroxyls radicals, nitric oxide, hydrogen peroxide radicals, superoxide radicals, and DPPH radical) scavenging activities of extracts from different Mentha spp [61, 62, 63] Agawane et al. [55] found that the methanolic leaves extract of Mentha arvensis L. showed ability to scavenge DPPH free radical which was found to be $78 \%$ at concentration $1000 \mathrm{mg} / \mathrm{mL}$. The effect of antioxidative components on inhibition of DPPH radical is considered to be due to their ability of hydrogen-donating [64].

The significant decrease of blood glucose level in these study are in agreement with that found by Hussain et al. [65], who observed that the mean blood glucose in diabetic mice decreased from 346 $(\mathrm{mg} / \mathrm{dl})$ to $140(\mathrm{mg} / \mathrm{dl})$ after treated with camel milk $(83 \mathrm{ml} / \mathrm{kg}$ body weight for 7 weeks) which is not significantly different from the diabetic mice receiving glibenclamide (antidiabetic druge) in a dose of $600 \mu \mathrm{g} / \mathrm{kg}$ body weight (blood glucose of $125 \mathrm{mg} / \mathrm{dl}$ ). Also, Shori and Baba [66], reported that the fermented plain camel milk had higher anti-diabetic activity than fermented plain cow milk. The orally intake of camel milk (at a dose of $250 \mathrm{ml} / 24$ hours/15 rats) reduced the blood glucose level from $462.3 \pm 37.8$ to $96.7 \pm 11.1 \mathrm{mg} / \mathrm{dL}$ [67]. While, oral administration of camel milk for three weeks decreased the level of blood glucose of alloxan-induced diabetic rats from $10.88 \pm 0.55$ to $6.22 \pm 0.5$ mmol/l [68]. In the same side, Hamad et al. [69] noted that the camel milk had the higher anti-diabetic activity (49\%) compared with buffalo and cow milk (11\%) in diabetic Sprague-Dawley rats. In Agrawal et al. [70, 71] work, the results observed that camel milk had a significant hypoglycemic effect when administered to type 1 diabetic patients as an adjunct therapy for 3 months. Also, Agrawal et al. [72] 
reported that camel milk as an adjunct to insulin therapy appears to be safe and efficacious in improving long-term glycemic control and helps in reduction in the doses of insulin in patients with type 1 diabetes. One of the suggested mechanisms of the anti-diabetic effect of camel milk might be attributable to the inhibition of various metabolic enzymes such as dipeptidyl peptidase IV [DPP-IV, an enzyme that degrades the insulin-secreting incretin hormones gastric inhibitory polypeptide (GIP) and glucagon-like peptide (GLP) , $\alpha$-glucosidase and $\alpha$-amylase [73]. The potential inhibition of DPP-IV is due to bioactive peptides resulting after hydrolysis of camel milk proteins throughout proteolysis or fermentation process [8], especially bioactive peptides released from whey proteins [74,75]. Additionally, presence of hydrophobic amino acids in the bioactive peptides is considered an additional factor for DPP-IV inhibition because these amino acids may further enhance interaction with the active site of DPP-IV $[76,77]$. Another study suggested that the anti-diabetic activity of camel milk due to its effect on the insulin receptors [78]. While Mehaia et al. [79] reported that the content of insulin-like proteins in camel milk was 3 times more than in cow milk.

In the present study, it was observed that the corporation between sage or mint powder and fermented camel milk increased the anti-diabetic activity (decreased glucose level and increased insulin level in blood plasma). This is due to anti-diabetic activity of sage and mint powder. According to the previous studies, the antidiabetic activity of sage leaves powder due to its activity in reduced the blood glucose level and also inhibits the activity of the intestinal maltase and sucrase enzymes [23, 80]. Jose et al. [81] found that the oral administration of Peppermint juice for 21 days significantly $(\mathrm{p}<0.0010)$ decreased the blood glucose level in alloxan induced diabetic rats. Diabetes is associated with an increase in oxidative stress as shown by an increase in free radicals, and decreased the activities of catalase (CAT), superoxide dismutase (SOD), glutathione S-transferase (GST), glutathione peroxidase (GPX) and GSH [82]. Free radicals play an important role in the development of both type I and type II diabetes [83]. Eidi et al. [84] reported that the elevation in plasma insulin levels in the sage extracttreated STZ diabetic rats could be due to substances present in the plant extract which stimulate insulin secretion or which protect the intact functional b-cells from further deterioration so that they keep active and continue to insulin production. Eidi et al. [84] showed that the methanol extract of S. officinalis causes a significant reduction in glucose concentrations on STZ -induced hyperglycemic rats. Also, Khashan and Al-Khefajim [23], found that the alloxan-induced diabetic rats treated with aqueous and ethanol extracts $(100 \mathrm{mg} / \mathrm{kg})$ of sage (Salvia officinalis) leaves showed a significant reduction $(\mathrm{P}<0.05)$ in fasting blood glucose. The effects of plants on diabetes disease were summarized in increasing 
insulin secretion, increasing glucose uptake by fat tissues and skeletal muscle, inhibiting the production of liver glucose, and inhibiting the absorption of glucose in the intestinal [24].

These results in agree with Mansour et al. [67] who noted that the oral administration of camel milk reduced the increased in TG, TC, LDL-C and VLDL-C in diabetic rats compared with the diabetic control group. Hanieh et al. [85] evaluated the effects of camel milk on the TC, HDL and TG levels in type 1D and type 2D respectively, their findings agreed with our results that, camel milk normalized the alteration in TG and HDL-c, while reduced the increase in total cholesterol (TC) levels. Therefore, camel milk can give promising results when used as dietary supplement for patients of type 1D. In the same side, Khattab et al. [86] found that treated diabetic rats with sage leaves induced significant improvement in lipid profile parameters as compared with the non-treated diabetic group and concluded that sage had a potent hypoglycemic activity and related this effect to its antioxidant activities.

Regulating the levels of cholesterol and triglyceride in the blood is an important way to protect humans from coronary heart disease. It was found that administration of sage infusion for 12 weeks reduced total cholesterol, triglycerides, low-density lipoprotein(LDL-c) in rats, while, HDL-c was increased [87]. Also, Khashan and Al-Khefajim [23] indicated that ethanolic and water extracts of Sage leaves significantly lowered cholesterol and TG levels. Moreover, many studies cleared the significant role of mint leaves on diabetic rats. This hypolipidemic effect of sage may be related to the inhibition of hepatic de novo synthesis or the activation of b-oxidation [87]. Barbalho et al.[88] reported that treatment of diabetic rats with $M$. piperita caused a reduction on the levels of cholesterol, LDL-c, and triglycerides and increase the levels of HDL-c. Also, Nickavar et al.[89] also found that treatment of hyperlipidemic rats with aqueous extract of Mentha piperita leaves extract for 21 days significantly reduced serum total cholesterol, triglycerides, and LDL-c, and associated with a significant increase in HDL-c levels and decrease in the atherogenic index in indicating its potent anti-hyperlipidemic and antiatherogenic activity.

AST, ALT, and LDH are enzymes mainly found in hepatocyte cytosol and cell membrane. They are good markers considerably used to evaluate hepatotoxicity and integrity of the membrane [90]. The increase in activities of plasma ALT, AST, ACP, ALP, and LDH mean that diabetes caused hepatic dysfunction. Therefore, the increment of the activities of ALT, AST, ACP, ALP, and LDH in plasma 
may be mainly due to the leakage of these enzymes from the liver cytosol into the bloodstream which gives an indication of the hepatotoxic effect of alloxan [91, 92]. Belhadj et al.[90] noted that increase in liver enzymes activities in diabetic rats were reduction after treated with sage essential oil. Similarly, in alloxan diabetic rats, ALT, AST, and ALP activities were superior to those in normal rats, but recovered after oral administration of fermented camel milk fortified with sage and mint powder. these results similar that found by Eidi et al. [84] who reported that the recovery of liver cell integrity was obtained after treatment by Sage. Orally administration of ethanolic extract of sage leaves to diabetic rats, lowered serum glucose, triglycerides, total cholesterol, urea, creatinine, AST, ALT, and enhanced plasma insulin depending on the increasing dose [93, 23].

Induction of hyperglycemia caused an increase in serum creatinine and urea levels, excessive proteinuria, and marked deterioration of kidney function, and microscopic examination of sections of the kidneys of diabetic animals showed pathological features of glomerulosclerosis, with abnormal extracellular matrix (ECM) accumulation, glomerular matrix expansion, tubular alveolar degeneration, and fibrosis, fourth, increased urinary excretion [12]. The observed increase in serum creatinine, urea, and uric acid of diabetic animals compared with the nondiabetic control group agree with Eidi and Eidi [93]. While, the consumption of camel milk caused a significant decreased in creatinine, urea of diabetic rats and this could be attributed to the hypoglycemic and antioxidant effects of camel milk [12]. The reported powerful hypoglycemic action of camel milk in diabetic patients is hypothesized to abolish the glucose-driven metabolic pathways. The intensive glycemic control in type 1 and type 2 diabetes mellitus patients results in a decrease in microalbuminuria. So, the observed renal protective effects of camel milk treatment, in diabetic rats, could be assigned to the glucose homeostatic action of camel milk. This was in accord with the earlier findings by Agrawal et al., [70] of a significant reduction of the microalbuminuria in type 1 diabetes mellitus patients receiving camel milk along with their standard antidiabetic therapy suggesting a direct protective effect of camel milk against diabetic nephropathy $[65,94,95]$.

Kilari et al. [96] found that the histology of liver and pancreatic tissue displayed the absence of lipid accumulation in hepatocytes and preservation of $\beta$-cells in camel milk protein hydrolysate treated groups compared with the diabetic control group. Our results cleared that orall administration of fermented camel milk fortified with sage and mint leaves powder showed restoration of insulin secretion in diabetic 
rats and this means that the Langerhans islets $\beta$-cells restored their activity. these results may be due to the regeneration has occurred of distorted $\beta$-cells, or the undamaged $\beta$-cells secretes insulin with overdose to compensate the shortage caused by damaged cells, or the camel milk reduced the damage in $\beta$-cells which related to alloxan, as well as the antioxidant activities of fermented camel milk, sage and mint powder [97,98, 99, 100, 101]. Mansour et al., [67] reported that Immunohistochemical findings revealed that Camel Milk administration restored the immunostaining reactivity of insulin and GLUT-4 in the pancreas of diabetic rats. We boosted our investigation by the immunohistochemical test. STZ induced diabetes by destroying the pancreatic $\beta$-cells $[102,103]$. Checking the amount of produced insulin is a good indicator of the normal case of Langerhans islets $\beta$-cells because the active insulin is secreted from secretory granules in the $\beta$-cells [104]. The results indicated that; the reduction of GLUT4 appeared in the diabetic rats (under immunohistochemical examination) reflects the decrease in insulin secretion. Because the expression of GLUT-4 is stimulated by cascade gene regulation enhanced by secretion of insulin hormone [105]. Administration of camel milk restored the expression of GLUT-4 in the pancreas tissue which is detected by the immunohistochemical staining, camel milk already contains insulin as mentioned in different articles $[106,107,108]$ as well as it restored the activity of the $\beta$-cells as we mentioned previously. Belhadj et al.[90], stated that the hepatic tissue in the Cont+ Sage EO group showed a good quality, similar to that examined in Cont group. Serum enzyme measurements are beneficial tool in clinical diagnosis, providing information on the effect and nature of pathological damage to any tissue in the body [109].

The increase in serum Alanine aminotransferase (ALT) and Aspartate aminotransferase (AST) activities may indicate liver tissue damage probably by altered cell membrane permeability leading to the leak of the enzymes from the tissues to the serum. Alanine and aspartate aminotransaminases are considered to be sensitive indicators of hepatocellular damage and within limit can provide a quantitative evaluation of the degree of damage to the liver [110]. Diabetes has a strong relationship with renal and liver diseases [111]. Camel milk protected the liver and kidney function from failure; we suppose that camel milk contains insulin nanoparticles that safeguard the role of kidney and liver by restoring the normal glucose levels in the blood. Korish et al. [12] found that the administration of camel milk to the control animals caused insignificant changes in the glomerulotubular morphology in comparison to the noncamel milk treated control animals . Furthermore, the kidney slices obtained from the diabetic animals and stained with the Hematoxylin and Eosin showed glomerular expansion and tubular alveolar degeneration. Eze et al. [112] mentioned that the induction with streptozotocin caused damage to the 
kidney tissue of diabetic rats, the untreated group showed severe glomerular necrosis with lymphocyte hyperplasia when compared with the normal. This result is similar to the work carried out by Trujillo et al. [113] who reported that the abnormal levels of serum urea usually signifies decreased renal function, so plasma urea is a recognized marker of glomerular filtration rate (GFR) and in nephropathy.

\section{Conclusion}

In this study camel milk supplemented with sage and mint leaves powder ameliorated and normalized the changes in glucose, total cholesterol, and triglycerides levels in the blood of diabetic rats. The best results were found with the fortification of fermented camel milk with sage leaves powder at a ratio of $1.5 \%$. The histopathological confirmed the biochemical assays results of insulin, glucose levels, and liver and kidney functions. From these results, it could be concluded that sage and mint leaves powder (at a ratio of $1.5 \%$ ) can be used to produce healthy and functional fermented camel milk with high antioxidant activity and anti-diabetic activity.

\section{Acknowledgements}

Not applicable.

\section{List of abbreviations}

CM: Camel milk, FCM: Fermented camel milk, DM: Diabetes mellitus, IDF: International Diabetes Federation, DPPH: 1, 1-diphenyl-2-picryl-hydrazyl, TPC: Total phenol content, FRAP: Ferric reducing antioxidant power, HDL-c: High density lipoprotein cholesterol, LDL-c: Low- density lipoprotein cholesterol, VLDL-c: Very low- density lipoprotein cholesterol, TG: Triglycerides, TC: total cholesterol, AST: aspartate transaminase, ALT: alanine transaminase, AlP: Alkaline phosphatase.

\section{Declarations}

\section{Ethics approval and consent to participate}

Ethics approval of studies using rats was obtained from Research Ethical Committee (REC), The Institutional Animal Care and Use Committee (ICUC), Tanta University, Egypt, (Approval number: IACUC-SCI-TU-0246), under Protocol entitled "The biological effects of Rayeb camel milk fortified with sage and mint leaves powder on alloxan-induced diabetic rats". Mice were maintained in the faculty 
778 of science, Tanta University, Egypt, according to recommendations in the Guide for the Care and Use of 779 Laboratory Animals of The Institutional Animal Care and Use Committee (ICUC).

\section{Consent for publication}

782 Not applicable.

783

\section{Availability of data and materials}

785 The data used during the study are available from the corresponding author on reasonable request. 786

\section{Competing interests}

788 The authors declare no competing interests

\section{Authors'contributions}

All the authors contributed to the work approved the final version of the manuscript. Particularly, contributions were: study design: MRS, MIE. Data collection: MRS, MIE, AAE; Data analyses and interpretation: MRS, MIE, AAE; Manuscript drafting: MRS, MIE; Critical revision of the manuscript: MRS, MIE, AAE. All authors read and approved the final manuscript.

\section{Author details}

${ }^{1}$ Department of Food Science and Technology, Faculty of Agriculture, Tanta University. Tanta, Egypt. ${ }^{2}$ Department of Pathology, Faculty of Veterinary Medicine - Suez Canal University, Ismailia, Egypt. ${ }^{3}$ Department of Dairy Technology Research, Food Technology Research Institute, Agricultural Research Center, Giza, Egypt. 


\section{$811 \quad$ Figure legend}

Figure (1): Effect of fermented camel milk fortified with sage and mint leave powders on glucose and insulin levels of normal and diabetic rats. Control (-): normal healthy rats; Control (+): control diabetic rats; FCM: fermented camel milk, FCMS1: fermented camel milk with $1.0 \%$ sage leave powder, FCMS2: fermented camel milk with 1.5\% sage leave powder, RCMM1: fermented camel milk with 1.0\% mint leave powder, FCMM2: fermented camel milk with 1.5\% mint leave powder. Values are expressed as mean $\pm S D, n=6$, Mean values in each column having different superscript $a, b, c, d$ are significant at $(p<0.05)$ by different and vice versa.

Figure (2): Effect of fermented camel milk fortified with sage and mint leave powders on lipid profile in plasma of normal and diabetic rats. Control (-): normal healthy rats; Control (+): control diabetic rats; FCM: fermented camel milk, FCMS1: fermented camel milk with 1.0\% sage leave powder, FCMS2: fermented camel milk with 1.5\% sage leave powder, RCMM1: fermented camel milk with 1.0\% mint leave powder, FCMM2: fermented camel milk with 1.5\% mint leave powder. Values are expressed as mean $\pm S D, n=6$, Mean values in each column having different superscript $a, b, c, d$ are significant at $(p<0.05)$ by different and vice versa.

Figure (3): Effect of fermented camel milk fortified with sage and mint leave powders on liver enzymes in plasma of normal and diabetic rats. Control (-): normal healthy rats; Control (+): control diabetic rats; FCM: fermented camel milk, FCMS1: fermented camel milk with 1.0\% sage leave powder, FCMS2: fermented camel milk with 1.5\% sage leave powder, RCMM1: fermented camel milk with 1.0\% mint leave powder, FCMM2: fermented camel milk with 1.5\% mint leave powder. Values are expressed as mean $\pm S D, n=6$, Mean values in each column having different superscript $a, b, c, d$ are significant at $(p<0.05)$ by different and vice versa.

Figure (4): Effect of fermented camel milk fortified with sage and mint leave powders on urea and creatinone levels of normal and diabetic rats. Control (-): normal healthy rats; Control (+): control diabetic rats; FCM: fermented camel milk, FCMS1: fermented camel milk with 1.0\% sage leave powder, FCMS2: fermented camel milk with 1.5\% sage leave powder, RCMM1: fermented camel milk with 1.0\% mint leave powder, FCMM2: fermented camel milk with 1.5\% 
mint leave powder. Values are expressed as mean $\pm S D, n=6$, Mean values in each column having different superscript $a, b, c, d$ are significant at $(p<0.05)$ by different and vice versa.

Figure (5) Effect of fermented camel milk fortified with sage and mint leaves powder treatment on pancreatic histopathology of the control and diabetic rats. A) normal healthy rats (Control-); B) control diabetic rats (Control +) ; C) fermented camel milk (FCM group); D) fermented camel milk with $1.0 \%$ sage leave powder (FCMS1 grouop), E) fermented camel milk with $1.5 \%$ sage leave powder (FCMS2 group), F) fermented camel milk with $1.0 \%$ mint leave powder(RCMM1 group ), G) fermented camel milk with 1.5\% mint leave powder (FCMM2 group).

Figure (6) Effect of fermented camel milk fortified with sage and mint leaves powder treatment on liver histopathology of the control and diabetic rats. A) normal healthy rats (Control-); B) control diabetic rats (Control +) ; C) fermented camel milk (FCM group); D) fermented camel milk with 1.0\% sage leave powder (FCMS1 grouop), E) fermented camel milk with $1.5 \%$ sage leave powder (FCMS2 group), F) fermented camel milk with 1.0\% mint leave powder(RCMM1 group ), $\boldsymbol{G}$ ) fermented camel milk with $1.5 \%$ mint leave powder (FCMM2 group).

Figure (7) Effect of fermented camel milk fortified with sage and mint leaves powder treatment on kidney histopathology of the control and diabetic rats. A) normal healthy rats (Control-); B) control diabetic rats (Control +) ; C) fermented camel milk (FCM group); D) fermented camel milk with 1.0\% sage leave powder (FCMS1 grouop), E) fermented camel milk with $1.5 \%$ sage leave powder (FCMS2 group), F) fermented camel milk with 1.0\% mint leave powder(RCMM1 group ), G) fermented camel milk with $1.5 \%$ mint leave powder (FCMM2 group). 


\section{References}

\section{FAO Stat, 2019. http://www.fao.org/faostat/en/\#home}

2. Ereifej KI, Alu'datt MH, AlKhalidy HA, Alli I, Rababah T. Comparison and characterization of fat and protein composition for camel's milk from eight Jordanian locations. Food Chem. 2011;127: 282-9.

3. Mati A, Senoussi-Ghezali C, Zennia SSA, Almi-Sebbane D, El-Hatmi H, Girardet J-M. Dromedary camel milk proteins, a source of peptides having biological activities-Areview. International Dairy Journal.2017;73: 25-37.

4. Kamal M, Karoui R. Monitoring of mild heat treatment of camel's milk by front-face fluorescence spectroscopy. LWT- -Food Sci Technol. 2017; 79: 586-93.

5. Swelum AA, El-Saadony MT, Abdo M, Ombarak RA, Hussein EOS, et al . Nutritional, antimicrobial and medicinal properties of Camel's milk: A review. Saudi Journal of Biological Sciences. 2021; 28: 3126-36.

6. Quan S, Tsuda H, Miyamoto T. Angiotensin I-Converting Enzyme Inhibitory Peptides in Skim Milk Fermented with Lactobacillus helveticus 130B4 from Camel Milk in Inner Mongolia, China. Journal of the Science of Food and Agriculture. 2008; 88: 2688-92. https://doi.org/10.1002/jsfa.3394

7. Agrawal RP, Tantia P, Jain S, et al. Camel milk: a possible boon for type 1 diabetic patients. Cell Mol Biol (Noisy-le-grand). 2013;59: 99-107.

8. Kamal H, Jafar S, Mudgil P, Murali C, Amin A, Maqsood S. Inhibitory properties of camel whey protein hydrolysates toward liver cancer cells, dipeptidyl peptidase-IV, and inflammation. J. Dairy Sci. 2018; 101:8711-20.

9. Solanki D, Hati S. Fermented Camel Milk: A Review on Its Bio-Functional Properties. Emirates Journal of Food and Agriculture. 2018; 30: 268-74. https://doi.org/10.9755/ejfa.2018.v30.i4.1661

10. El-Sayed M I, Awad S, Abou-Soliman NHI. Improving the Antioxidant Properties of Fermented Camel Milk Using Some Strains of Lactobacillus. Food and Nutrition Sciences. 2021; 12: 352-71.

11. International Diabetes Federation, IDF Diabetes Atlas, 10th edn, International Diabetes Federation, Brussels, Belgium. 2021. https://diabetesatlas.org/atlas/tenth-edition/

12. Korish AA, Abdel Gader A, Korashy HM, Al-Drees A, Alhaider AA, Arafah MM. Camel milk attenuates the biochemical and morphological features of diabetic nephropathy: Inhibition of Smad1 and collagen type IV synthesis. Chemico-Biological Interactions. 2015;229: 100-8.

13. Al Kury LA, Abdoh A, Ikbariah K, Sadek B, Mahgoub M. In Vitro and In Vivo Antidiabetic Potential of Monoterpenoids: An Update. Molecules. 2022; 27: 182. https://doi.org/10.3390/molecules27010182

14. Mohammadabadi T. The unique effects of camel milk as adjunctive super food on the health. World Journal of Pharmaceutical Sciences. 2021; 9(5): 97-106.

15. Meena S, Rajput YS, Pandey AK, et al. Camel milk ameliorates hyperglycaemia and oxidative damage in type-1 diabetic experimental rats. J Dairy Res. 2016; 83:412-9.

16. Badr G, Sayed LH, Omar HE-DM, et al. Camel whey protein protects B and T cells from apoptosis by suppressing activating transcription factor-3 (ATF-3)-mediated oxidative stress and enhancing phosphorylation of AKT and IjB-a in type I diabetic mice. Cell Physiol Biochem. 2017; 41:41-54.

17. Agrawal RP, Saran S, Sharma P, Gupta RP, Kochar DK, Sahani MS. Effect of camel milk on residual beta cell function in recent onset type 1 diabetes . Diabetes Res Clin Pract. 2007a; 77: 494 -5 . 
18. Fallah Z, Feizi A, Hashemipour M, Kelishadi R. Effect of fermented camel milk on glucose metabolism, insulin resistance, and inflammatory biomarkers of adolescents with metabolic syndrome: A double-blind, randomized, crossover trial. J Res Med Sci. 2018; 23:32.

19. Eftekhari A, Khusro A, Ahmadian E, Dizaj SM, Hasanzadeh A, Cucchiarini M. Phytochemical and nutra-pharmaceutical attributes of Mentha spp.: A comprehensive review. Arabian Journal of Chemistry. 2021; 14: 03106

20. Rajeshwari CU, Preeti M, Andallu B. Efficacy of mint (Mentha spicata L.) leaves in combing oxidative stress in type 2 diabetes. International journal of life sciences. 2012; 1(1): 1-7.

21. Chandirasegaran G, Elanchezhiyan C, Suhasini S, Babby A. Antihyperglycemic activity of menthe piperita ethanol leaves extract on streptozotocininduced diabetic rats. International journal for pharmaceutical research scholars. 2014; 3: 1-3.

22. Hamidpour M, Hamidpour R, Hamidpour S, Shahlari M. Chemistry, pharmacology, and medicinal property of sage (salvia) to prevent and cure illnesses such as obesity, diabetes, depression, dementia, lupus, autism, heart disease, and cancer, J. Tradit. Complement. Med. 2014; 4: 82-8. https://doi.org/10.4103/2225-4110.130373

23. Khashan K T, Al-Khefajim KA. Effects of Salvia officinalis L. (sag) leaves extracts in normal and alloxan -induced diabetes in white rats. International Journal of Scientific \& Engineering Research. 2015; 61: 20-8.

24. Mahdizadeh R, Moein S, Soltani N, Malekzadeh K, Mahmoodreza M. Study the molecular mechanism of salvia species in prevention of diabetic. International Journal of Pharmaceutical Sciences and Research. 2018; 9: 4512-21.

25. Öztürk Hİ, Aydın S, Sözeri D, Demirci T, Sert D, Akın N. Fortification of settype yoghurts with Elaeagnus angustifoliaL. flours: Effects on physicochemical, textural, and microstructural characteristics. LWT - Food Science and Technology. 2018; 90: 620-26

26. Abirami A, Nagarani G, Siddhuraju P. In Vitro Antioxidant, Antidiabetic, Cholinesterase and Tyrosinase Inhibitory Potential of Fresh Juice from Citrus hystrix and C. maxima Fruits. Food Science and Human Wellness. 2014; 3: 16-25. https://doi.org/10.1016/j.fshw.2014.02.001

27. Barros L, Cabrita L, Boas MV, Carvalho A M, Ferreira ICFR. Chemical, biochemical and electrochemical assays to evaluate phytochemicals and antioxidant activity of wild plants. Food Chemistry. 2011; 127: 1600-08.

28. Lim YY, Quah EPL. Antioxidant Properties of Different Cultivars of Portulaca oleracea. Food Chemistry. 2007; 103: 734-40. https://doi.org/10.1016/j.foodchem.2006.09.025

29. Oyaizu M. Studies on Products of Browning Reaction: Antioxidative Activities of Products of Browning Reaction Prepared from Glucosamine. Japan Journal of Nutrition. 1986; 44: 307-15. https://doi.org/10.5264/eiyogakuzashi.44.307

30. AOAC. Official Methods of Analysis of the Association Analytical Chemists. 18th Edition, Association of Official Analytical Chemistry, Gaithersburg. 2005.

31. Tamime AY, Robinson RK. Tamime and Robinson's Yoghurt: Science and Technology, $3^{\text {rd }}$ edn. 2007; 11-118. Cambridge, UK: Woodhead Publishing Limited.

32. Desai NS, Bhide H G. Hypoglycemic effect of Hantitonia Suave lens. Indian Med. 1985; 81: 86-91. 
33. NDDG. The National Diabetes Data Group: Classification and diagnosis of diabetes mellitus and other categories of glucose intolerance. Diabetes. 1994; 28: 1039-57.

34. AIN. American Institute of Purified Diet for Laboratory Rodent, Final Report; J. Nutr. 1993; 123:1939-51.

35. Childs AC, Phaneuf SL, Dirks AJ, Phillips T, Leeuwenburgh C. Doxorubicin treatment in vivo causes cytochrome $\mathrm{C}$ release and cardiomyocyte apoptosis, as well as increased mitochondrial efficiency, superoxide dismutase activity, and Bcl-2: Bax ratio. Cancer Res. 2002; 62: 4592-8.

36. Althnaian T, Albokhadaim I, El-Bahr SM. Biochemical and histopathological study in rats intoxicated with carbon tetrachloride and treated with camel milk. Springer plus. 2013; 2: 57.

37. El-Demerdash FM, Yousef MI, Abou El-Naga NI. Biochemical study on the hypoglycemic effects of onion and garlic in alloxan-induced diabetic rats. Food and Chemical Toxicology. 2005; 43(1): 57-63.

38. Trinder P. Determination of glucose in blood using glucose oxidase with an alternative oxygen acceptor. Annals of Clinical Biochemistry. 1969; 6: 24-7.

39. National Diabetes Data Group. Classification and diagnosis of diabetes mellitus and other categories of glucose intolerance. Diabetes. 1979; 28: 1039-57.

40. Chaney AL, Marbach EP. Modified reagents for determination of urea and ammonia. Clin Chem.1962; 8: 130-2.

41. Searcy RL, Reardon JE, Foreman JA. A new photometric methods for serum urea nitrogen determination. Amer J med Technol. 1967; 33: 15-20.

42. Tabacco A, meiattinim F, Moda E, Tarli P. Simplified enzymic/colorimetric serum urea nitrogen determination. Clin Chem. 1979; 25: 336-7.

43. Bartels H, Böhmer M. Eine mikromethode zur kreatininbestimmung. Clin Chem Acta. 1971; 32: 815.

44. Fabiny DL, Ertingshausen G. Automated reaction-rate method for determination of serum creatinine with cintrifiChem.Clin Chem. 1971; 17: 696-700.

45. Bucolo G, David H. Quantitative determination of serum triglycerides by use of enzymes. Clin Chem. 1973; 19: 476-82.

46. Fossati P, Prencipe L. Serum triglycerides determined colorimetrically with an enzyme that produces hydrogen peroxide. Clin Chem. 1982; 28: 2077-80.

47. Meiattini F, Prencipe L, Bardille F, Giannini G, Tarli P. The 4-hydroxybenzoate/4aminophenazone chromogenic system used in the enzymic determination of serum cholesterol. 1978; 24: 2161-5.

48. Grove $\mathrm{TH}$. The effect of reagent $\mathrm{pH}$ on determination of high-density lipoprotein cholesterol by precipitation of with sodium phosphotungstate-magnesium. Clin Chem. 1979; 25: 560-4.

49. Burstein M, Scholnick HR, Morfin R. Rapid method for isolation of lipoproteins from human serum by precipitation with polyanions. Scand J Clin Lab Invest. 1980; 40:583-95.

50. Reitman S, Frankel S. A colorimetric method for the determination of serum glutamic oxaloacetic and glutamic pyruvic transaminases. American Journal of Clinical Pathology. 1957; 26: 56-63. 
51. Belfield A, Goldberg DM. Enzyme. 1971; 12: 561.

52. Abraham, E.C.; Huff, T. A.; Cope, N.D.; Wilson, J.B.; Bransome, E. D., and Huisman, T.H. (1978): Determination of the glycosalated heamoglobin $(\mathrm{Hb})$ with a new microcolumn procedure. Suitability of the technique for assessing the clinical management of diabetes mellitus. Diabetes, 27(9): 931-7.

53. Wilson, M.A., and L.E. Miles, (1977): Radioimmunoassay of Insulin in Handbook of Radio Immunoassay G.E. Abraham, Ed., M. Inc. New York, pp: 275.

54. Bancroft D, Stevens A, Turmer R. Theory and practice of histological technique. 4th ed. Churchill Living Stone; Edinburgh, London, Melbourne. 1996; pp. 47-67.

55. Agawane SB, Gupta VS, Kulkarni M J, Bhattacharya A K, Koratkar S S. Chemo-biological evaluation of antidiabetic activity of Mentha arvensis L. and its role in inhibition of advanced glycation end products. Journal of Ayurveda and Integrative Medicine. 2019; 10: 166-70

56. Shori AB. Camel milk as a potential therapy for controlling diabetes and its complications: a review of in vivo studies. J Food Drug Anal. 2015; 23:609-18.

57. Ayoub MA, Palakkott A, Ashraf A, Iratn R. The molecular basis of the anti-diabetic properties of camel milk. Diabetes Research and Clinical Practice. 2018; 146: 305-12.

58. Molitch ME, DeFronzo RA, Franz MJ, Keane WF, Mogensen CE, Parving HH, Steffes MW. Nephropathy in diabetes. Diabetes Care. 2004; 27 (1): S79-S83.

59. Samarth R M. Protection against radiation induced hematopoietic damage in bone marrow of Swiss albino mice by Mentha piperita(Linn). Journal of Radiation Research. 2007; 48 (6): 523-8.

60. Samarth R M, Samarth M. Protection against radiationinduced testicular damage in Swiss Albino Mice by Mentha piperita (Linn.),'Basic and Clinical Pharmacology and Toxicology. 2009; 104 (4): 329-34.

61. Sun Z, Wang H, Wang J, Zhou L, Yang P. Chemical composition and anti-inflammatory, cytotoxic and antioxidant activities of essential oil from leaves of Mentha piperita grown in China. PloS one. 2014; 9 (12):114767.

62. Brahmi F, Boulkbache-makhlouf L, Yalaoui-guellal D, Chibane M, Madani K. Comparative study on the antioxidant effect of aqueous and ethanolic extracts of Mentha pulegium L. grown at two different locations. PhytoChem BioSub J. 2014; 8: 138-49.

63. Fatiha B, Didier H, Naima G, Khodir M, Martin K, Le'ocadie K, Caroline S, Mohamed C, Pierre D.. Phenolic composition,in vitro antioxidant effects and tyrosinase inhibitory activity of three Algerian Menthaspecies: M. spicata (L.), M. pulegium (L.) and M. rotundifolia(L.) Huds (Lamiaceae). Ind. Crops Prod. 2015; 74: 722-30.

64. El-Sayed MI, Ibrahim A A, Awad S. Impact of Purslane (Portulaca oleracea L.) Extract as Antioxidant and Antimicrobial Agent on Overall Quality and Shelf Life of Greek-Style Yoghurt. Egypt. J. Food. Sci. 2019; 47 (1): 51 - 64. 
1036

1037

1038

1039

1040

1041

1042

1043

1044

1045

1046

1047

1048

1049

1050

1051

1052

1053

1054

1055

1056

1057

1058

1059

1060

1061

1062

1063

1064

1065

1066

1067

1068

1069

1070

1071

1072

1073

1074

1075

1076

1077

1078

1079

1080

65. Hussain H, Wattoo FH, Wattoo MHS, Gulfraz M, Masud T, Shah I, Ali S, Alavi S. Camel milk as an alternative treatment regimen for diabetes therapy. Food Sci Nutr. 2021; 9:1347-56.

66. Shori A B, Baba A S. Comparative antioxidant activity, proteolysis and in vitro $\alpha$-amylase and $\alpha$ glucosidase inhibition of Allium sativum-yogurts made from cow and camel milk. J. Saudi Chem. Soc. 2014; 18:456-63.

67. Mansour AA, Nassan MA, Saleh OM, Mohamed M S. Protective Effect Of Camel Milk As AntiDiabetic Supplement: Biochemical, Molecular And Immunohistochemical Study. Afr J Tradit Complement Altern Med. 2017; 14 (4): 108-19. https://doi.org/10.21010/ajtcam.v14i4.13

68. Sboui A, Khorchani T, Djegham M, Agrebi A, Elhatmi H. Anti-diabetic effect of camel milk in alloxan induced diabetic dogs: a dose-response experiment. J Anim Physiol Anim Nutr (Berl). 2010; 94: 540-6.

69. Hamad E, Abdel-Rahim E, Romeih E. Beneficial effect of camel milk on liver and kidneys function in diabetic Sprague-Dawley rats. International Journal of Dairy Science. 2011; 6(3): 190-7. https://doi.org/10.3923/ijds.2011.190.197

70. Agrawal RP, Swami SC, Beniwal R, Kochar DK, Sahani MS, Tuteja FC, Ghouri SK. Effect of camel milk on glycemic control, lipid profile and diabetes quality of life in type 1 diabetes: a randomised prospective controlled cross over study. Indian J Animal Sci. 2003;73:1105-10.

71. Agrawal RP, Dogra R, Mohta N, Tiwari R, Singhal S, Sultania S. Beneficial effect of camel milk in diabetic nephropathy, Acta Biomed. Atenei Parmensis. 2009; 80: 131-4.

72. Agrawal RP, Beniwal R, Sharma S, Kochar DK, Tuteja FC, Ghorui SK, Sahani MS. Effect of raw camel milk in type 1 diabetic patients: 1 year randomised study. J Camel Pract Res. 2005;12:2735.

73. Mudgil P, Kamal H, Yuen G C, Maqsood S. Characterization and identification of novel antidiabetic and anti-obesity peptides from camel milk protein hydrolysates. Food Chem. 2018; 259:46-54. https: / / doi .org/ 10 .1016/ j .foodchem .2018.03.082.

74. Nongonierma A B, Cadamuro C, Le Gouic A, Mudgil P, Maqsood S, FitzGerald R J. Dipeptidyl peptidase IV (DPPIV) inhibitory properties of a camel whey protein enriched hydrolysate preparation. Food Chem. 2019; 279:70-9.

75. Mudgil P, Baby B, Ngoh Y-Y, Kamal H, Vijayan R, Gan C-Y, Maqsood S. Molecular binding mechanism and identification of novel anti-hypertensive and anti-inflammatory bioactive peptides from camel milk protein hydrolysates. Lebensm. Wiss. Technol. 2019; 112:108-93. https: // doi .org/ 10 .1016/ j .lwt .2019.05.091.

76. Nongonierma A B, FitzGerald R J. Features of dipeptidyl peptidase IV (DPP-IV) inhibitory peptides from dietary proteins. J. Food Biochem. 2019; 43:e12451. https: / / doi .org/ 10 .1111/ jfbc .12451.

77. Ashraf A, Mudgil P, Palakkott A, Iratni R, Gan C. et al. Molecular basis of the anti-diabetic properties of camel milk through profiling of its bioactive peptides on DPP-IV and insulin receptor activity. J. Dairy Sci. 2020; 104:61-77.

78. Abdulrahman AO, Ismael MA, Al-Hosaini K, et al. Differential effects of camel milk on insulin receptor signaling - toward understanding the insulin-like properties of camel milk. Front Endocrinol. 2016; 7:4.

79. Mehaia MA, Hablas MA, Abdel-Rahman KM, et al. Milk composition of Majaheim, Wadah and Hamra camels in Saudi Arabia. Food Chem. 1995; 52:115-22.

80. Gayathri GA, Mahalingam G. Review on enhancement of glucose uptake and up-regulation of glucose transporters by antidiabetic medicinal plants. Asian J Pharm Clin Res. 2016; 9(2): 34-9. 
1081

1082

1083

1084

1085

1086

1087

1088

1089

1090

1091

1092

1093

1094

1095

1096

1097

1098

1099

1100

1101

1102

1103

1104

1105

1106

1107

1108

1109

1110

1111

1112

1113

1114

1115

1116

1117

1118

1119

1120

1121

1122

1123

81. Jose A, Kumer SS, Mukkadan JK. A study on anti-diabetic effect of peppermint in alloxan induced diabetic model of Wister rats. J Cline Biomed Sci. 2013; 3 (4): 1777-1781.

82. Awad S, El-Sayed MI, Wahba A, El Attar A, Yousef MI, Zedan M. Antioxidant activity of milk protein hydrolyaste in alloxan-induced diabetic rats. Journal of Dairy Science. 2016; 99: 8499510.

83. Marjani A. Lipid peroxidation alterations in type 2 diabetic patients. Pak. J Biol. Sci. 2010; 13:72330.

84. Eidi M, Eidi A, Zamanizadeh H. Effect of Salvia officinalisL. leaves on serum glucose and insulin in healthy and streptozotocin-induced diabetic rats. J Ethnopharmacol. 2005;100: 310-3.

85. Hanieh SE, Amir NN, Parvin M, Maryam ZY, Mehdi H, Fereidoun A, Aliakbar MM. Effect of camel milk on blood sugar and lipid profile of patients with type 2 diabetes: A pilot clinical trial. Int J Endocrinol Metab. 2015; 13:21160.

86. Khattab HAH, Mohamed R A, Hashemi J M. Evaluation of Hypoglycemic Activity of Salvia officinalis L. (Sage) Infusion on Streptozotocin-Induced Diabetic Rats. J Am Sci. 2012; 8(11):40610.

87. Hernández-Saavedra D, Pérez-Ramírez IF, Ramos-Gómez M, Mendoza-Díaz S, Loarca-Pina G, Reynoso-Camacho R. Phytochemical characterization and effect of Calendula officinalis, Hypericum perforatum, and Salvia officinalis infusions on obesity-associated cardiovascular risk. Med Chem Res. 2016; 25:163-72.

88. Barbalho S M, Damasceno DC, Spada APM, Da SilvaVS, Mratuchi KA, Oshiiwa M. Metabolic profile of offspring from Diabetic wistar rats treated with Mentha pierita (Peppermint). Evidence based complementary and alternative medicine. 2011; Article ID. 430237, doi: $10.1155 / 2011 / 430237$

89. Nickavar B, Abolhasani L, Izadpanah H. Alpha-amylase Phenolic profile and free radicalscavenging activity of Cabernet Sauvignon wines of different geographical origins from the Balkan region. J. Sci. Food Agric. 2008; 90: 2455-61.

90. Belhadj S, Hentati O, Hammami M, Ben Hadj A, Boudawara T, Dammak M, Zouari S, El Feki A. Metabolic impairments and tissue disorders in alloxan-induced diabetic rats are alleviated by Salvia officinalis L. essential oil. Biomedicine \& Pharmacotherapy. 2018; 108: 985-95.

91. Bouché C, Serdy S, Kahn CR, Goldfine AB. The cellular fate of glucose and its relevance in type 2 diabetes. Endocr. Rev. 2004; 25: 807-30, https://doi.org/10.1210/er.2003-0026

92. El-Sayed MI, Awad S, Wahba A, El Attar A, Yousef MI and Zedan M. In Vivo Anti-diabetic and Biological Activities of Milk Protein and Milk Protein Hydrolyaste. Advances in Dairy Research. 2016; 4: 1-6.

93. Eidi A, Eidi M. Antidiabetic effects of sage (Salvia officinalis L.) leaves in normal and streptozotocin-induced diabetic rats. Diabetes \& Metabolic Syndrome: Clinical Research \& Reviews. 2009; 3: 40-4.

94. Mohamad RH, Zekry ZK, Al-Mehdar HA, Salama O, El-Shaieb SE, ElBasmy AA, Al-said MG, Sharawy S.M. Camel milk as an adjuvant therapy for the treatment of type 1 diabetes: verification of a traditional ethnomedical practice, J. Med. Food. 2009; 12 : 461-5.

95. Agrawal RP, Jain S, Shah S, Chopra A, Agarwal V. Effect of camel milk on glycemic control and insulin requirement in patients with type 1 diabetes: 2 -years randomized controlled trial. Eur. J. Clin. Nutr. 2011; 65: 1048-52. 
96. Kilari B P, Mudgil PP, Azimullah S, Bansal N, Ojha S, Maqsood S. Effect of camel milk protein hydrolysates against hyperglycemia, hyperlipidemia, and associated oxidative stress in streptozotocin (STZ)-induced diabetic rats. Journal of Dairy Science. 2020; 104 (2): 1304-17.

97. Srinivasan K, Ramarao P. Animal models in type 2 diabetes research: An overview. Indian J Med Res. 2007; 125: 451-72.

98. Afifi MEM. Effect of camel's milk on cisplatin-induced nephrotoxicity in swiss albino mice. Am J Biochem Biotechnol. 2010; 6:141-7.

99. Al-Fartosi KG, Khuon OS, Al-Tae HI. Protective role of camel's milk against paracetamol induced hepatotoxicity in male rats. Int J Res Pharmaceut Biomed Sci. 2011; 2: 1795-9.

100. Khan AA, Alzohairy M. Hepatoprotective effects of camel milk against CCl4-induced hepatotoxicity in Rats. Asian J Biochem. 2011; 6: 171-80.

101. Zeineb J, Jean-Michel G, Isabelle A, Nadia O, Pascal D, Touhami K, Halima EH. Antioxidant activity of camel milk casein before and after in vitro simulated enzymatic digestion. Mljekarstvo. 2014; 64: 287-94.

102. Eleazu CO, Eleazu KC, Chukwuma S, Essien UN. Review of the mechanism of cell death resulting from streptozotocin challenge in experimental animals, its practical use and potential risk to humans. J Diabetes Metab Disord. 2013; 12: 12-60.

103. Sharma R, Yadav R, Manivannan E. Study of Effect of Stevia Rebaudiana bertoni on oxidative stress in type-2 diabetic rat models. Biomed Aging Pathol. 2012; 2: 126-31.

104. Agrawal RP, Budania S, Sharma P, Gupta R, Kochar DK. Zero prevalence of diabetes in camel's milk consuming Raica community of northwest Rajasthan, India. Diabetes Res. Clin. Pract. 2007b; 76: 290-6.

105. Gisela W. Insulin and insulin resistance. Clin Biochem Rev. 2005; 1: 19 -39.

106. Malik A, Al-Senaidy A, Skrzypczak-Jankun E, Jankun J. A study of the anti-diabetic agents of camel milk. Int J Mol Med. 2012; 30: 585-92.

107. Al-Hashem F. Camel milk protects against aluminum chloride-induced toxicity in the liver and kidney of white albino rats. Am J Biochem Biotechnol. 2009; 5: 98-108.

108. Abd El-Aziz AD, Ali KA, Ahmed AH, Mansour HZ, Mohamed MS. A study on the effect of female camel (Camelus dromedarius) milk on glycemic control of streptozotocin (STZ) induced diabetes mellitus in rats. J American Science. 2012; 8: 459-65.

109. Wills DE. Biochemical Basis of medicine. 3rd Edn., John Wright and sons Ltd., Bristol, England. $1985 ; 267-8$.

110. Al-Habori M, Al-Aghbari AM, Al-Mamary B M. Toxicological Evaluation of Catha Edulis Leaves. A Long Term Feeding Experiment in Animals. J Ethnopharmacol. 2002; 83: 209-17.

111. Mazen A, John EG. Hypoglycemia in patients with diabetes and renal disease. J Clin Med. 2015; 4: 948-64. 
1160 112. Eze ED, Aliyu M, Yusuf T, Abubakar A.Effects of lycopene on kidney antioxidant enzyme activities and functions in streptozotocin-induced diabetic Wistar rats. Cell Biology. 2015; 3 (1): $1-13$.

1163 113. Trujillo J, Chirino YI, Molina-Jijon E, Anderica-Romero AC, Tapia E, PedrazaChaverri J. Renoprotective effect of the antioxidant curcumin: Recent findings. Redox Biology. 2013; $1(1): 448-56$.

1166

1167 